\title{
The Relationship between Social Skills, Executive Functions, and Story Comprehension in Children with and without Specific Language Impairment
}

\author{
Juhee Mun, Dongsun Yim \\ Department of Communication Disorders, Ewha Womans University, Seoul, Korea
}

Correspondence: Dongsun Yim, PhD Department of Communication Disorders, Ewha Womans University, 52 Ewhayeodae-gil, Seodaemun-gu, Seoul 03760, Korea Tel: $+82-2-3277-6720$

Fax: +82-2-3277-2122

E-mail: sunyim@ewha.ac.kr

Received: September 30, 2020

Revised: October 30, 2020

Accepted: November 5, 2020

This work was supported by the Ministry of Education of the Republic of Korea and National Research Foundation of Korea(NRF2018S1A3A2075274).

\begin{abstract}
Objectives: This study aimed to compare and examine the correlation between the social skills (problem solving, emotional expression, sense of order, and confidence), executive function (updating, inhibition, and shifting), and story comprehension ability of children with and without Specific Language Impairment (SLI). Also, this study investigated if social skills and executive function predict the performance in the story comprehension task in each group. Methods: A total of 33 children (14 children with SLI and 19TD children) aged 4 to 7 years participated in this study. Parents assessed their children's social skills using the Korean-Social Skill Rating Scale for Preschoolers (K-SSRSP). Children performed the tasks of executive function and story comprehension. Results: Children with SLI received significantly lower scores than TD children on the K-SSRSP. Also, children with SLI performed significantly lower than TD children in inhibition, shifting and story comprehension tasks. In TD children, there was a positive correlation between story comprehension ability and updating ability. In children with SLI, story comprehension ability was positively correlated with problem solving and emotional expression. Moreover, in TD children, updating ability significantly predicted their story comprehension ability. On the other hand, in children with SLI, the factors predicting their story comprehension ability were found to be problem solving and emotional expression among social skills. Conclusion: These results present the necessity to look into the social skills when evaluating and intervening with children with SLI or when advising non-experts such as parents or caregivers.
\end{abstract}

Keywords: Social skills, Executive function, Story comprehension, Specific language impairment
사회성 기술은 타인과 상호작용하며 반응하는데 쓰이는 전략으 로, 인간이 사회의 구성원으로서 수용되며 건강하게 살아가기 위 해 사회성 기술의 적절한 발달은 필수적이다(McFall, 1982). 사회성 기술은 영아기 주양육자와의 관계부터 시작하여 아동이 어린이집 이나 유치원, 학교 등에서 또래를 포함한 다양한 사람들과 관계를 맺으면서 자연스럽게 발달하는데, 이것이 적절하게 발달하지 않으 면 살아가는데 많은 어려움을 겪을 수 있다. 예를 들어, 사회성 기 술 요소 중 하나로 볼 수 있는 자신감과 관련하여, 수줍음이 많은 사람들은 사회적인 문맥 속에서 스스로가 서툴다고 생각하여 불 편함을 느끼고 새로운 사회적 환경에 적응하는데 어려움을 경험하
며(Durkin, Toseeb, Botting, Pickles, \& Conti-Ramsden, 2017), 관 계 형성의 문제나 지연, 또래로부터의 거부, 부정적인 자기인식 등을 경험한다고 보고되었다(Coplan, Closson, \& Arbeau, 2007; Rowsell \& Coplan, 2013).

사회성 기술이 언어 이전기부터 발달한다는 증거는 선행연구들 에 의해 제시되어 왔으며, 영유아는 태어나는 순간부터 자신의 환 경 내에 있는 성인과 사회적 상호작용을 시작한다(Whaley, 1990). 생애 초기의 성인과의 놀이는 영유아에게 사회적 상호작용의 규칙 (주고받기, 사회적 역할 등)을 학습하고 연습할 수 있는 기회를 제 공하며(Bruner \& Sherwood, 1976), 이후에 나타나는 또래와의 상 
호작용 능력은 이러한 부모와의 놀이 경험으로부터 길러지게 된다 (Vandell, Wilson, \& Buchanan, 1980). 즉, 관계 속 사회적 능력의 발달은 매우 이른 시기인 생애 첫 해부터 시작되는 것으로 오랫동 안 연구되어 왔다(Brownell \& Brown, 1992; Howes, 1988; Vandell \& Wilson, 1987). 영유아기의 사회성 기술 발달의 가장 대표적인 예 는 공동주의(joint attention)로, 공동주의는 사회적 주의를 조정할 수 있는 능력으로 성공적인 상호작용을 위한 복잡한 사회적 역량 을 갖추는데 필수적인 요소이다(Hecke et al., 2007; Mundy \& Sig$\operatorname{man}, 2006)$. 공동주의에 내포된 상대방과의 호의적 상호작용에 대 한 동기는 타인의 반응에 대한 이해 및 감정 공유와 관련된 친사회 적 행동의 발달로 이어지게 된다(Parlade et al., 2009).

사회성 기술에 관해서는 다양한 정의가 존재하는데, Gresham (2002)은 사회성 기술이 독립성, 자기결정, 책임감 요인 등을 포함 하는 적응행동과 참여, 협력, 문제해결, 자기주장, 자신감 요인 등을 포함하는 사회기능으로 구성된다고 하였다. 또한 사회성 기술은 일 상에서 또래 관계를 만들고, 타인과 상호작용하며 반응하는데 쓰 이는 전략이라고도 정의되며(McFall, 1982), 사회성 기술의 예로는 집단 활동 참여, 타인에 대한 관심 표현, 사회적 문제해결 등이 있다 (Jamison, Forston, \& Stanton-Chapman, 2012). 또한 Yoon (2008) 은 인간이 다양한 사회 환경에서 스스로를 인지하고 타인과 관계 를 맺고 유지하는 등 유능한 구성원으로서 적응 및 성장하기 위해 필요한 능력을 사회성 기술로 정의하였다.

학령전기 및 아동 초기는 이러한 사회성 기술 발달에 매우 중요 한 시기로, 이 시기에 습득하는 사회성 기술은 아동이 미래에 행복 하고 잘 적응한 개인으로 사는 것을 도와준다(Pekdoğan, 2016). 따 라서 학령전기 아동들의 행동을 유심히 관찰할 필요가 있으며, 이 들의 사회성 기술 발달을 도와주어 잠재적인 문제를 예방할 수 있 어야 한다(Alisinanoğlu \& Kesicioğlu, 2010; Karg1 \& Erkan, 2004). 학령전기 아동들은 가정과는 사회생태학적으로 다른 환경인 어린 이집 및 유치원을 경험하게 된다(Corsaro, 1988). 이때 아동들은 처 음으로 가족 이외의 사회를 본격적으로 경험하기 시작하는데(McClelland \& Morrison, 2003), 여기서 경험하는 또래 관계는 아동이 가족으로부터 얻은 사회성 기술을 더 연습하고 발달시킬 기회를 제공한다(Alpan, 2006). 또한, 아동들은 교사 및 다른 아동들과의 관계에 활용하기 위해 가정 환경에서는 필요하지 않았던 새로운 사 회적 기술을 습득하기도 한다(McClelland \& Morrison, 2003). 아 동들은 유치원 환경 속에서 또래 문화를 만들고 유지하며, 사회적 정체성을 구축하고, 참여 욕구를 발달시키며, 교사의 규칙을 경험 하기도 한다(Corsaro, 1988). 이 시기에 사회성 기술을 적절하게 습 득하지 못하면 청소년기와 성인기의 행동문제로 이어질 수 있으며
(Gülay \& Akman, 2009; Ladd, 1999), 사회성과 관련된 행동문제들 이 적절하게 다뤄지지 않으면 미래에 심각한 문제를 초래할 수 있다 (Gülay \& Akman, 2009).

특히, 아동은 4 세부터 타인과의 관계 속에서 발생하는 문제를 인 지 및 해결하는 능력이 형성된다고 보고되었다(Shure \& Spivack, 1974). 또한, Ellis와 Siegler (1994)는 아동이 이 시기에 교육기관과 또래 관계를 경험하고 언어능력이 점차 발달함에 따라 문제를 논리 적으로 해결하는 능력이 향상된다고 하였다. 아동기에 사회적 문제 해결 능력이 적절히 발달하지 않으면 또래로부터 거부되는 등 부적 응을 경험할 수 있으며, 이는 청소년기 및 성인기까지 이어질 수 있 어 이 시기의 문제해결 능력의 발달은 사회 속에서 어울려 살아가 는데 매우 중요하게 작용한다(Kupersmidt, Coie, \& Dodge, 1990). 또한, 아동 초기는 사회적 적응에 중요한 정서 발달에도 매우 주요 한 시기이다. 이 시기는 아동이 정서와 관련된 상황에 관한 세밀한 분석을 통해 인과관계를 파악할 수 있게 되며, 정서를 표현하는 방 식이 변화하는 등 정서 이해 및 표현의 큰 발달이 이루어지는 시기 이다(Stegge \& Terwogt, 2007). 신생아도 기쁨, 슬픔과 같은 기본적 인 정서를 안면 표정으로 표현할 수 있지만 이는 정서가 덜 분화된 상태이며(Lee, 2014; Park, 2014), 아동기부터 자신의 정서에 대한 이 해 및 설명과 타인의 정서에 대한 인식 능력이 발달된다(Ryu \& Min, 2003). 또한, 아동기부터 정서를 조절하는 능력을 습득하는데, 이는 미래의 대인관계 형성과도 크게 연관된다고 밝혀졌다(Cole, Martin, \& Dennis, 2004). 4세 아동들은 정서 유발 상황에 관해 설명할 수 있게 되고(Denham \& Zoller, 1991), 타인의 표정 및 몸짓을 활용 하여 감정을 추론할 수 있으며(Boone \& Cunningham, 1998), 표면 적으로 드러난 정서와 실제 정서가 다를 수 있음을 알게 된다(Harris, 1989). 아동은 특히 학령전기부터 경험하는 사회적 망의 확장 을 통해 정서에 관한 정보를 새로 획득하고(Park, 2014), 일상에서 정서와 관련된 다양한 경험을 통해 정서를 조절하며 타인과의 효 율적인 상호작용이 가능해진다(Lee, 2014). 이러한 정서 이해, 표현 및 조절 능력이 적절히 발달해야 사회에 문제없이 적응할 수 있게 된다(Eisenberg, Fabes, Guthrie, \& Reiser, 2000).

아동의 사회성 기술을 측정하는 방법으로는 행동 평가 척도, 직 접적인 관찰, 상황극 평가 등이 있다. 그 중 행동 평가 척도는 개인 의 특성 및 행동을 요약하여 보여주는 효율적인 도구로 사회성 기 술을 평가하는데 가장 많이 사용되고 있다(Elliott \& Busse, 2004). 아동의 사회성 기술을 측정하는 행동 평가 척도의 대표적인 예로 Social Skills Rating System (SSRS; Gresham \& Elliott, 1990), Social Skills Improvement System-Rating Scales (SSIS-RS; Gresham \& Elliott, 2008), Preschool and Kindergarten Behavior Scales, 2nd 
edition (PKBS-2; Merrell, 1994) 등이 있다. SSRS (Gresham \& Elliott, 1990)는 3세부터 학령기까지의 아동을 대상으로 3점 척도로 평가하며, 아동의 부모 혹은 교사가 평가하거나 고학년 학생은 자 기평가를 할 수 있게 되어 있다. 또한, 3 가지 영역(사회성 기술, 문제 행동, 학업적 유능성)을 포함하고 있으며 이 중 사회성 기술 영역은 협동, 주장, 자기조절의 하위척도로 총 30 문항으로 구성된다. SSISRS (Gresham \& Elliott, 2008)는 SSRS를 개정한 평가로 기존의 하 위척도에 4 가지 하위척도(의사소통, 관계, 책임감, 공감)가 추가되 었으며 3세부터 18세까지를 대상으로 한다. PKBS-2 (Mereell, 1994)는 3세부터 6세의 아동을 대상으로 아동의 부모나 교사 등이 4점 척도로 평가할 수 있다. 또한, 사회성 기술과 문제 행동 영역을 포함하는데 사회성 기술 영역은 3 가지 하위척도(사회적 협동, 사회 적 상호작용, 사회적 독립성)로 34문항으로 구성된다. 과거 국내에 는 표준화된 평가 도구가 없었기 때문에 이러한 외국의 평가 도구 들을 번안하여 사용하였으나, 현재 국내에도 아동의 사회성 기술 을 객관적으로 평가할 수 있는 한국 유아 사회성 기술검사(Korean-Social Skill Rating Scale for Preschoolers, K-SSRSP; Yoon, 2012) 가 개발되어 사용되고 있다.

최근, 타인과 상호작용하는데 중요하게 사용되는 사회성 기술과 언어능력 간 밀접한 관련이 있다는 연구들이 진행되고 있는데 특 히, 단순언어장애 아동은 사회적 어려움을 경험한다는 보고들이 지속적으로 발표되고 있다(Conti-Ramsden \& Botting, 2004; Lindsay, Dockrell, \& Strand, 2007). 단순언어장애 아동의 친사회적 행 동은 일반 아동에 비해 덜 발달된 것으로 교사와(Hart, Fujiki, Brinton, \& Hart, 2004; Timler, 2008) 부모에 의해 보고되었고(StantonChapman, Justice, Skibbe, \& Grant, 2007), 5세에서 7세 사이에 단 순언어장애 아동의 사회성 문제가 지속적으로 유지된 것이 확인되 었다(Redmond \& Rice, 2002). 단순언어장애 아동은 다양한 측면 으로 사회적 어려움을 경험하는데, 갈등 상황이 주어졌을 때 문제 해결을 위해 또래 일반 아동보다 더 적은 전략을 사용하며, 특히 설 득하기, 상황을 명료화하거나 더 많은 정보를 얻기 위해 질문하기, 다른 사람의 관점에서 바라보기와 같은 전략들을 사용하는데 어 려움이 있다고 밝혀졌다(Stevens \& Bliss, 1995). Marton, Abramoff 와 Rosenzweig (2005)의 연구에서도, 단순언어장애 아동이 갈등 상황에서 갈등을 직접 해결하기보다는 회피하려 하거나 제 3 자가 해결해주기를 기대하는 등 수동적으로 반응한다는 것을 확인하였 다. 또래와의 상호작용 상황에서 단순언어장애 아동의 협상능력을 살펴본 연구에서는, 단순언어장애 아동들이 또래 일반 아동에 비 해 유의하게 적고 낮은 수준의 협상 전략을 사용하였다(Brinton, Fujiki, \& McKee, 1998). 또한, 정서에 대한 경험, 조절, 이해, 표현 능
력은 사회적 유능성에 매우 중요하게 작용하는데 단순언어장애 아 동들은 이에 관해서도 어려움을 경험한다(Izard et al., 2001). 교사 의 체크리스트를 통해 단순언어장애 아동과 또래 일반 아동의 정서 조절 능력을 측정하고 비교한 결과, 단순언어장애 아동의 정서조절 능력이 유의하게 낮은 것으로 나타났다(Fujiki, Brinton, \& Clarke, 2002). 단순언어장애 아동과 또래 일반 아동을 대상으로 특정한 사 회적 상황에서 경험하게 될 감정을 추론하는 과제를 실시한 연구 에서도 단순언어장애 아동의 수행력이 더 낮았다(Ford \& Milosky, 2003). 단순언어장애 아동은 또래와의 관계 및 자신감 측면에서도 어려움을 보이는데, 이들은 일반 아동과 비교하였을 때, 또래와의 접촉이 적고(Fujiki, Brinton, \& Todd, 1996), 친구들에게서 덜 선호 되는 경향이 있다(Gertner, Rice, \& Hadley, 1994). 또한, 단순언어 장애 아동들은 혼자 놀고수줍음을 보일 확률이 높으며(Fujiki, Brinton, Isaacson, \& Summers, 2001), 또래 일반 아동에 비해 자존감 및 자신감이 낮은 경향이 있다(Rice, 1993).

한편, 집행기능은 목표지향적인 행동을 실행하기 위해 다양한 인지 및 사고 과정들의 작동을 조절 및 통제하는 기제이다(Miyake et al., 2000). 집행기능은 갱신 능력(updating), 억제 능력(inhibition), 전환 능력(shifting)을 핵심 하위 기능으로 포함하며(Miyake et al., 2000), 이 하위 기능들은 서로 관련이 있지만 분리 가능하다(Miyake et al., 2000; Vaughan \& Giovanello, 2010). 갱신 능력은 정보 를 기억 속에 저장하고 새로운 정보의 입력 시 이를 심적으로 조작 하여 수정할 수 있는 능력이며, 억제 능력은 부적절한 우세 반응이 나 외부의 방해자극으로부터 주의를 억제할 수 있는 능력이다. 또 한 전환 능력은 과제의 요구나 규칙이 변경될 시, 이에 유연하게 적 응할 수 있는 능력을 의미한다(Diamond, 2013). 아동이 사회의 구 성원으로서 살아가기 위해서는 타인의 의도를 인식하고 이러한 정 보에 기반하여 다양한 상황적 문맥에 따라 적절하게 집행기능을 사용함으로써 자신의 행동과 목표를 조절할 수 있어야하므로(Huy$\operatorname{der} \&$ Nilsen, 2012), 집행기능 역시 사회성 기술과 마찬가지로 타인 과 함께하는 건강한 삶을 위해 중요한 요소로 작용한다. 집행기능 은 학령전기와 학령기에 지속적으로 발달되는데 아동들은 이 시기 에 정서적으로 성숙하고 유연해지며 사회적 적응 능력의 발달을 경 험한다(Diamond, 2006; Lafreniere, 1996). 또한 사회적 상호작용 을 통해, 기초적인 집행기능이 더 복잡하고 심화된 단계의 집행기 능 기술로 발달하게 된다(Cock et al., 2017).

집행기능과 언어능력 역시 서로 관련이 있는 것으로 밝혀지고 있 는데 Key-DeLyria와 Altmann (2016)은 실시간으로 이루어지는 담 화를 이해하기 위해 갱신 능력이 요구되며, 발화 내 적절한 어휘를 걸러내기 위해 억제 능력이 필요하고, 문장의 문법적 분석을 위해 
서는 전환 능력이 사용된다고 주장하며 언어 처리 과정에서의 집행 기능의 역할을 강조하였다. 5 세부터 8 세 아동을 대상으로 한 Kim 과 Phillips (2014)의 연구에서는 아동의 억제 능력이 듣기 이해력과 정적 상관이 있는 것으로 나타났으며, Magimairaj와 Montgomery (2013)의 연구에서는 아동의 청각 및 시각적 전환 능력이 언어 지시 이해 능력을 예측하였다. 또한 아동의 어휘 능력은 억제 능력과 정 적 상관이 있는 것으로 밝혀졌다(Roebers \& Schneider, 2005). 이러 한 결과들로 보았을 때, 아동의 집행기능은 언어의 다양한 영역과 관련이 있는 것으로 보인다.

언어능력과 집행기능 간의 관계는 일반 아동과 장애 아동 모두 에게서 나타나는데(Hughes, 1998; Remine, Care, \& Brown, 2008) 특히 단순언어장애 아동의 경우 비록 진단 기준에 인지 발달의 어 려움은 포함되지 않지만, 이들은 집행기능과 같은 영역에서도 결함 을 보인다(Kapa \& Plante, 2015). 단순언어장애 아동과 또래 일반 아동의 집행기능을 비교한 결과, 단순언어장애 아동의 언어 및 비 언어적 갱신 능력, 비언어적 전환 능력, 언어적 억제 능력이 유의하 게 낮은 것으로 나타났다(Kapa, Plante, \& Doubleday, 2017). Yim, Yang, Jo, Lee와 Seong (2015)의 연구에서는 단순언어장애 아동이 언어적 갱신 과제, 억제 과제, 전환 과제에서 일반 아동보다 유의하 게 낮은 수행력을 보였으며, Yim, Yang과 Song (2019)은 단순언어 장애 아동의 비구어적 갱신 능력과 억제 능력이 이들의 수용 및 표 현 어휘능력, 수용 및 표현 언어능력과 모두 유의한 상관이 있음을 밝혀내었다. Gathercole와 Baddeley (1990)의 연구에서는 단순언어 장애 아동이 갱신 능력을 측정하는 비단어 따라말하기 과제의 3,4 음절 조건에서 일반 아동보다 낮은 수행력을 보였다. 단순언어장애 아동과 또래 일반 아동을 대상으로 방해자극에 대한 반응을 억제 하고 목표자극에만 반응해야 하는 과제를 실시한 결과, 단순언어 장애 아동의 수행력이 유의하게 더 낮았다(Spaulding, 2010). 또한, 전환 능력은 새로운 어휘 학습, 어휘 간의 연결, 통사구조 등 언어 습득에 매우 중요한 역할을 하므로 단순언어장애 아동과 관련이 있다고 보고되었다(Collisson, Grela, Spaulding, Rueckl, \& Magnuson, 2015; Samuelson \& Smith, 2000; Smith, Jones, \& Landau, 1996).

사회성 기술과 집행기능은 모두 사회의 구성원으로서 타인과 함 께 조화롭게 사는데 매우 중요한 능력이며 이들은 서로 관련이 있 는 것으로 밝혀지고 있다(Alduncin, Huffman, Feldman, \& Loe, 2014; Rhoades, Greenberg, \& Domitrovich, 2009). 또한, 사회성 기 술과 집행기능은 언어능력과도 관련이 있다는 증거들이 제시되고 있지만 이를 종합적으로 다룬 연구는 제한적이다. 특히, 단순언어 장애 아동은 사회 속 하나의 구성원으로 타인과 원활하게 상호작
용하고 변화하는 상황에 적절히 대응하기 위해 갖추어야 할 사회 성 기술과 집행기능에 결함이 있는 것으로 보인다. 따라서 본 연구 는 단순언어장애 아동 및 또래 일반 아동의 사회성 기술 및 집행기 능과 언어능력 간의 관계를 살펴보는데 주목적을 두고 있다. 본 연 구에서는 그림과 함께 제시되는 이야기를 듣고 수행하며, 어휘 및 구문 등의 이해(Crais \& Chapman, 1987; Graybeal, 1981), 제시된 정보의 분류, 사건의 인과관계 파악, 내용에 대한 구체적인 회상, 명 시적으로 제시되지 않은 정보에 관한 추론(Morrow, 1985) 등을 복 합적으로 요구하는 이야기 이해 과제 수행력을 언어능력을 대표하 는 능력으로 측정하였다.

이야기 이해는 기존의 지식과 제시된 정보를 활용하여 이야기의 의미를 파악하는 과정으로(Chae, 2001), 표면적으로 드러난 정보 를 이해하는 참조적 이해와 표면적으로 드러나지는 않지만 제시된 정보들과 기존의 지식을 통합하여 숨겨진 내용을 파악하는 추론 적 이해로 나눌 수 있다(Desmarais, Nadeau, Trudeau, FiliatraultVeilleux, \& Maxès-Fournier, 2013). 이야기 이해 과정은 단어, 구, 문장의 의미 및 구문에 대한 파악을 요구하며(Daneman \& Merikle, 1996) 아동의 언어능력을 반영하고 예측하는 요인으로 밝혀졌다 (Khan et al., 2016). 이야기 과제는 의미론, 구문론, 형태론, 화용론 등 언어의 전반적인 영역들을 적절히 활용한 사고의 구성을 요구하 며(Kim \& Pae, 2004), 학령전기 언어발달장애 아동들의 이야기 산 출, 회상 및 이해 능력은 미래에 나타날 수 있는 아동의 언어 문제를 예측하는 지표로 나타났다(Kim \& Pae, 2004). 일반적으로 4세 아 동도 이야기에 관한 추론적 이해가 가능하다고 보고되었으며(Filiatrault-Veilleux, Bouchard, Trudeau, \& Desmarais, 2016; van Kleeck, 2008). 단순언어장애 아동도 일반 아동처럼 이야기 구조에 대한 개 념과 이야기 문법 범주에 관한 지식을 가지고 있다고 밝혀졌다(Kim \& Pae, 2004; Merritt \& Liles, 1987). 문해능력이 완전히 발달하지 않은 학령전기 아동을 대상으로 이야기 이해 능력을 파악할 경우 읽기 능력의 영향을 받지 않아야 한다(van den Broek et al., 2005). 어린 아동의 이야기 이해 능력을 측정하는 과제에서 자극을 제공 하는 방법으로는 구어 없이 그림 자극만 제공되는 경우, 그림과 함 께 구어 자극이 제공되는 경우, 구어 자극만 제공되는 경우가 있는 데, 많은 연구들이 그림을 보여주며 성인이 직접 이야기를 들려주 거나 녹음된 음성으로 이야기를 들려주는 방법을 사용한다(Filiatrault-Veilleux et al., 2016; Kendeou, van den Broek, White, \& Lynch, 2009; Khan et al., 2016; Lynch et al., 2008; Storch \& Whitehurst, 2002). 또한, 아동이 질문에 답하는 방식의 이야기 이해 과제는 이 야기 속 인물과 사건의 원인 및 결과를 이해하였는지, 명확히 드러 나지 않은 내용에 관해 추론할 수 있는지 등 이해 능력을 평가하는 
과제로 널리 사용되고 있다(Freedle, 1979).

본 연구는 단순언어장애 아동과 또래 일반 아동의 사회성 기술, 집행기능, 이야기 이해 과제 수행을 살펴보고 이 변인들 간의 상관 관계를 밝혀내고자 하였다. 또한, 사회성 기술 및 집행기능이 이야 기 이해 능력을 유의하게 예측할 수 있는지 확인해보고자 하였다. 연구 질문은 다음과 같다.

1) 사회성 기술 영역(문제해결, 정서표현, 질서의식, 자신감)에 따 라 집단(단순언어장애 아동, 일반 아동) 간 점수에 유의한 차 이가 있는가?

2) 3 가지 집행기능 과제(갱신 능력, 억제 능력, 전환 능력) 및 이야 기 이해 과제에서 집단(단순언어장애 아동, 일반 아동) 간 수 행에 유의한 차이가 있는가?

3) 각 집단(단순언어장애 아동, 일반 아동)의 사회성 기술 및 집 행기능은 이야기 이해 능력과 유의한상관관계가 있는가?

4) 각 집단(단순언어장애 아동, 일반 아동)의 사회성 기술 및 집 행기능은 이야기 이해 능력을 유의하게 예측하는가?

\section{연구방법}

\section{연구대상}

본 연구에서는 서울 및 경기도에 거주하는 만 4-7세의 단순언어 장애 아동 14 명 $(\mathrm{M}=65.00, \mathrm{SD}=13.71)$, 일반아동 19 명 $(\mathrm{M}=66.47$, $\mathrm{SD}=8.07)$, 총 33 명을 대상자로 선정하였다. 단순언어장애 아동의 선정 기준은 Leonard (1998)의 기준을 참고하여 (1) 한국 카우프만 아동 지능검사(Korean Kaufman Assessment Battery for Children, K-ABC; Moon \& Byun, 2003)의 동작성 지능 검사 결과 85점(-1 SD) 이상이며, (2) 취학전 아동의 수용언어 및 표현언어 발달척도(Preschool Receptive-Expressive Language Scale, PRES; Kim, Sung, \& Lee, 2003) 결과 표현언어에서 $10 \%$ ile 미만의 수행력을 보이고, (3) 부모 및 교사에 의해 지적능력, 신경학적 손상, 구강 구조나 기능 등 에 이상이나장애가 없다고 보고된 아동으로 선정하였다.

일반 아동은 (1) 한국 카우프만 아동 지능검사(Korean Kaufman Assessment Battery for Children, K-ABC; Moon \& Byun, 2003)의 동작성 지능 검사 결과 85점(-1 SD) 이상이며, (2) 취학전 아동의 수 용언어 및 표현언어 발달척도(Preschool Receptive-Expressive Language Scale, PRES; Kim et al., 2003) 결과 수용언어 및 표현언어 모 두 $10 \%$ ile 이상의 수행력을 보이고, (3) 부모 및 교사에 의해 지적능 력, 신경학적 손상, 구강 구조나 기능 등에 이상이나 장애가 없다고 보고된 아동으로 선정하였다. 또한, 본 연구에 참여한 모든 단순언 어장애 아동 및 일반 아동을 대상으로 수용 및 표현 어휘력 검사
Table 1. Participants' characteristics

\begin{tabular}{lcc}
\hline & SLI $(\mathrm{N}=14)$ & TD $(\mathrm{N}=19)$ \\
\hline Age $(\mathrm{mo})$ & $65.00(13.71)$ & $66.47(8.07)$ \\
Nonverbal IO & $104.00(11.29)$ & $110.68(10.73)$ \\
PRES & & \\
$\quad$ Receptive & $32.79(5.98)$ & $50.05(9.54)$ \\
$\quad$ Expressive & $29.71(9.50)$ & $48.79(7.22)$ \\
REVT & & \\
Receptive & $47.50(17.18)$ & $71.53(10.30)$ \\
Expressive & $50.57(14.80)$ & $75.47(9.50)$ \\
\hline
\end{tabular}

Values are presented as mean (SD).

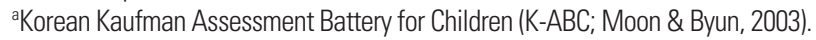
$S L I=$ children with specific language impairment; $T D=$ typically developing children; PRES = Preschool Receptive-Expressive Language Scale (Kim, Sung, \& Lee, 2003); REVT= Receptive \& Expressive Vocabulary Test (Kim, Hong, Kim, Jang, \& Lee, 2009).

(Receptive \& Expressive Vocabulary Test, REVT; Kim, Hong, Kim, Jang, \& Lee, 2009)를 실시하여 대상자의 언어적 특성을 추가적으 로 살펴보았다. 본 연구 대상자의 생활연령, 동작성 지능, 언어 검사 점수의 평균 및 표준편차는 Table 1에 제시하였다.

집단 간 통제가 잘 이루어졌는지 알아보기 위해 일원배치분산분 석을 실시하였다. 분석 결과, 두 집단간 생활연령 $\left(F_{(1,31)}=.150, p=.701\right)$ 및 동작성 지능 $\left(F_{(1,31)}=2.995, p=.093\right)$ 에 통계적으로 유의한 차이가 없었다. 그러나 수용언어능력 $\left(F_{(1,31)}=35.454, p=.000\right)$ 및 표현언어 능력 $\left(F_{(1,31)}=43.050, p=.000\right)$, 수용어휘력 $\left(F_{(1,31)}=25.103, p=.000\right)$ 및 표현어휘력 $\left(F_{(1,31)}=34.680, p=.000\right)$ 에서 집단 간 차이가 유의하 게 나타났다.

\section{연구과제}

한국 유아 사회성 기술 검사(K-SSRSP)

아동들의 사회성 기술을 측정하기 위해 한국 유아 사회성 기술 검사(Korean-Social Skill Rating Scale for Preschoolers, K-SSRSP; Yoon, 2012)를 실시하였다. 본 검사는 아동에 대한 직접적인 관찰 과 판단에 근거하여 부모나 주양육자 혹은 교사의 보고로 평가한 다. 본 검사의 문항은 문제해결(13문항), 정서표현(15문항), 질서의 식(6문항), 자신감(6문항) 영역으로, 총 40 문항으로 구성되었다. 모 든 문항은 5점 척도로 구성되었으며, 1 점은 전혀 아님( $0 \%), 2$ 점은 약간 그러함(30\%), 3점은 보통(50\%), 4점은 대체로 그러함(70\%), 5 점은 항상 그러함(100\%)에 해당되었다. 문항의 예시로는 문제해 결의 경우 '문제가 발생할 때 친사회적인 방법으로 해결한다.'가 있 으며, 정서표현의 경우 '무섭거나 두려운 이유를 말로 표현한다.'가 있다. 또한, 질서의식 문항의 예시는 '또래와 놀이나 게임을 할 때 규 칙을 잘 지킨다.'가 있으며, 자신감의 경우 ‘또래에게 자기 의사를 당 
당하게 말한다.'가 있다. 추가적인 검사 문항의 예시는 Appendix 1 에 제시하였다.

\section{갱신 과제: 매트릭스(Matrix)}

아동들의 갱신 능력을 측정하기 위해 매트릭스 과제(Yim \& Yang, 2018)를 실시하였다. 컴퓨터 화면을 통해 $3 \times 3$ 매트릭스에 $500 \mathrm{~ms}$ 간격으로 주황색 불이 점등되는 것이 보여지면 아동은 점등되었던 네모 칸의 순서를 그대로 기억했다가 반응해야 한다. 네모 칸들이 순차적으로 점등된 후 정지 화면이 나타났다가 다시 $3 \times 3$ 매트릭스 화면이 제시되면 아동이 해당 네모 칸을 순차적으로 손가락으로 짚어 반응하도록 하였다. 본 과제는 점등되는 칸의 수를 기준으로 총 4 단계로 구성되었다. 1 단계에서는 2 개, 2 단계에서는 3 개, 3 단계 에서는 4 개, 4 단계에서는 5 개의 칸이 점등되었다. 1 단계와 2 단계는 각각 4 문항씩, 3 단계와 4 단계는 각각 5 문항씩으로 총 18 문항으로 구성되었다. 과제의 예시는 Figure 1에 제시하였다.

억제 과제: Fruit Stroop Task

아동들의 억제 능력을 측정하기 위해 fruit stroop 과제(Yim, Yang et al., 2019)를 실시하였다. 본 과제는 3 단계로 구성되었으며 각 단계 에서는 $5 \times 3$ 의 배열로 총 15 개의 자극이 제시된다. 1 단계에서는 4 가지 색깔로 구성된 네모들이 자극으로 주어지며, 네모의 색깔을 순서대로 소리내어 말하도록 한다. 2 단계에서는 4 가지 종류의 과일

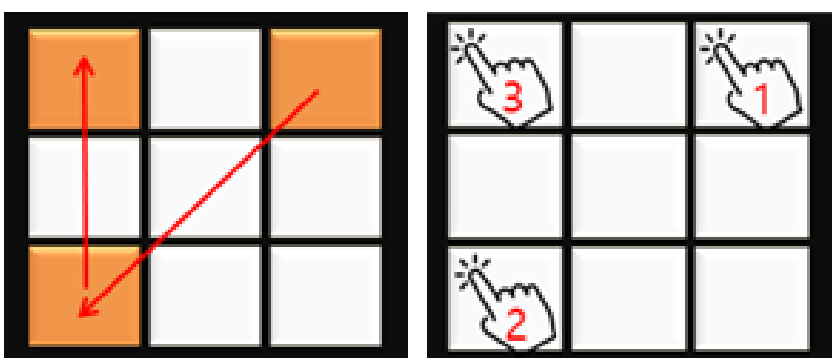

Figure 1. Example of matrix task to examine updating ability.
들이 자극으로 주어지며, 과일의 색깔을 순서대로 소리내어 말하도 록 한다. 3 단계에서는 2 단계에 제시되었던 과일들이 잘못 색칠되어 자극으로 주어지며, 과일의 원래 색깔을 순서대로 소리내어 말하도 록 한다. 각 단계마다 45 초의 시간이 주어지며, 제한시간 안에 최대 한 정확하고 빠르게 색깔 이름을 말해야 한다. 또한, 제한 시간 안에 주어진 15 개의 자극에 대해 모두 반응한 경우, 다시 첫 번째 자극으 로 돌아가서 순차적으로 말하도록 하였다. 과제의 예시는 Figure 2 에 제시하였다.

\section{전환 과제: 차원전환카드분류 과제(DCCS)}

아동들의 전환 능력을 측정하기 위해 차원전환카드분류 과제 (Yang \& Yim, 2018)를 실시하였다. 본 과제는 전환 이전 단계, 전환 이후 단계, 심화 단계, 총 3 단계로 구성되었다. 그림 자극으로는 빨 간 토끼, 초록 토끼, 빨간 배, 초록 배가 사용되었으며 목표자극은 중앙에, 2 개의 보기자극은 목표자극의 좌우 양옆에 제시되었다. 전 환 이전 단계는 색깔게임으로 좌우에 제시되는 2 개의 보기자극 중 목표자극과 같은 색깔의 자극을 골라 반응하도록 한다. 전환 이후 단계는 모양게임으로 좌우에 제시되는 2 개의 보기자극 중 가운데 제시되는 목표자극과 같은 모양의 자극을 골라 반응하도록 한다. 심화 단계는 색깔게임과 모양게임이 결합된 형태로 좌우에 2 개의 보기자극이 제시되는데, 가운데 나타나는 목표자극이 검은 사각
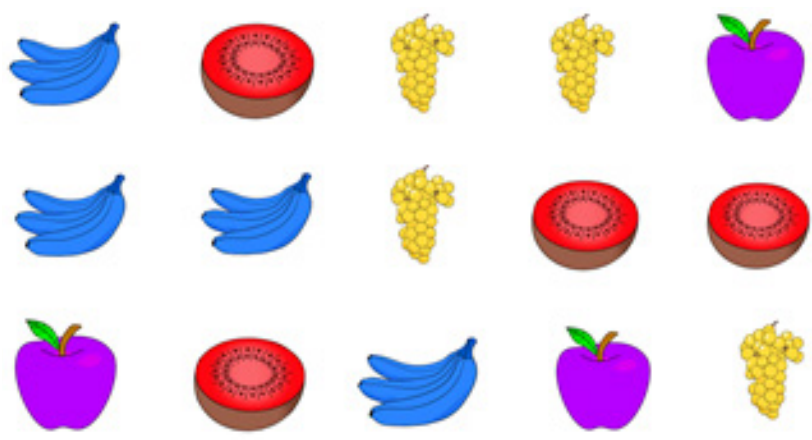

Figure 2. Example of fruit Stroop task to examine inhibition ability.
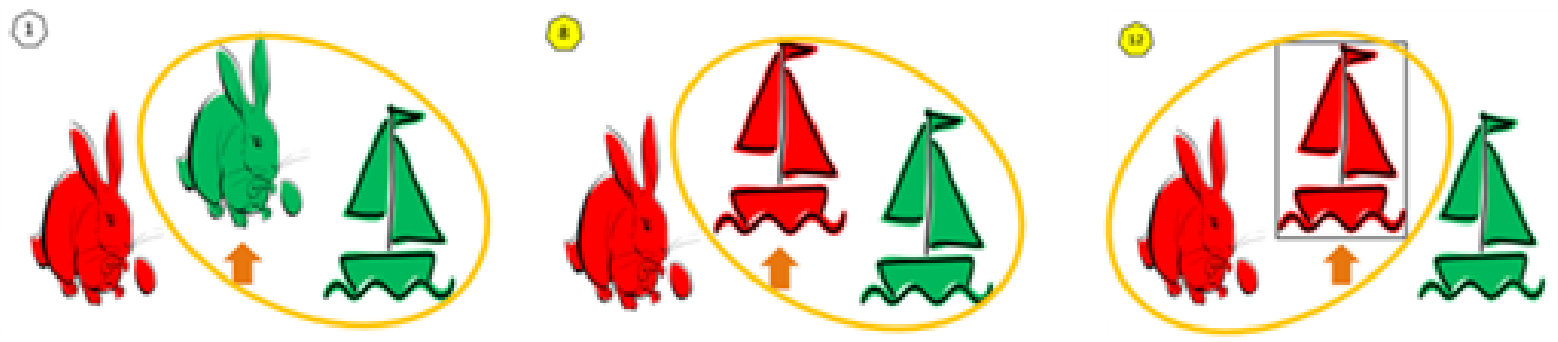

Figure 3. Examples of DCCS task to examine shifting ability. 
테두리 안에 있으면 색깔게임 규칙을 따르고 목표자극이 검은 사 각 테두리 없이 제시되면 모양게임 규칙을 따라 반응해야 한다. 본 과제는 전환 이전 단계 6문항, 전환 이후 단계 6문항, 심화 단계 12 문항으로 구성되었다. 과제의 예시는 Figure 3에 제시하였다.

\section{이야기 이해 과제}

아동들의 이야기 이해 능력을 측정하기 위해 페파피그 이야기 이해 과제(Cho \& Yim, 2020)를 수정하여 실시하였다. 아동은 컴퓨 터 화면을 통해 15 컷의 그림을 보면서 녹음된 음성으로 나오는 이 야기를 들은 후, 내용과 관련된 질문에 구어로 답하도록 하였다. 본 과제는 참조적 이해 질문 5 문항, 추론적 이해 질문 6 문항, 총 11 문항 으로 구성되었다. 참조적 이해 질문은 이야기에서 표면적으로 드러 난 정보에 관한 질문이었으며, 추론적 이해 질문은 표면적으로 드 러나지 않았지만 이야기에서 주어진 정보들을 통합하고 활용하여 추론해야 하는 질문으로 구성되었다. 이야기의 내용은 또래와의 관계에서 갈등이 발생하고 화해하는 과정이었으며, 이해 질문에는 이야기에서 제시된 장소나 물건 등을 묻는 문항들과 사건과 관련 된 인물의 감정, 의도, 일어나지 않은 일에 관한 추론 등을 묻는 문 항들이 포함되었다. 페파피그 이야기 이해 과제 기록지는 Appen$\operatorname{dix} 2$ 에 제시하였다.

\section{연구절차}

본 실험에 앞서 본 연구의 이야기 이해 과제의 난이도가 연구 대 상자의 연령에 적절한지 확인하기 위해 예비실험을 실시하였다. 만 4 세 일반 아동 2 명, 만 5 세 일반 아동 3 명, 만 7세 일반 아동 2 명, 만 6 세 단순언어장애 아동 1 명을 대상으로 과제를 실시하였다. 그 결과, 예비실험에 참여한 아동 모두 적절하게 과제를 수행할 수 있었으 며, 과제가 연구 대상자의 연령에 적절한 난이도임을 확인하였다.

선별 검사와 본 검사는 2 회기에 걸쳐 진행되었다. 첫 회기는 1 시 간 내외로 선별 검사를 진행하였으며 두 번째 회기는 약 30 분 간 본 검사를 진행하였다. 본 검사의 경우, 억제 과제, 갱신 과제, 전환 과 제, 이야기 이해 과제 순으로 진행되었다. 선별 검사와 본 검사 시행 중 지속적으로 아동의 상태를 확인하였으며, 아동이 피로를 호소 하는 경우 휴식을 가진 후 검사에 다시 참여할 수 있도록 하였다.

한국 유아사회성 기술 검사(Korean-Social Skill Rating Scale for Preschoolers, K-SSRSP; Yoon, 2012)는 본 연구에 참여한 대상자 모 두 부모가 직접 평가하였으며 평가는 소음이 없는 조용한 장소에서 진행되었다. 평가 전 아동의 부모가 평가 방법을 충분히 숙지하도록 설명하였으며, 정확하게 알지 못한다는 문항에 대해서는 연구자가 문항 관련 상황들에 관한 추가적인 질문을 통해 파악하여 평가하
도록 하였다. 예를 들어, 문제해결 영역 중 '문제가 발생할 때 친사회 적인 방법으로 해결한다.'의 문항에 관해 아동의 부모가 이해하지 못한 경우, '아동이 친구와 장난감을 가지고 놀던 중 갈등 상황이 발 생했을 때, 양보하기, 적절한 방법으로 순서 정하기 등의 행동을 보 이는지 혹은 빼앗기, 때리기 등의 행동을 보이는지'와 같이 구체적 인 상황 및 아동의 반응을 제시하여 부모의 이해를 도왔다.

모든 집행기능 과제는 소음이 없는 조용한 장소에서 아동과 검 사자가 일대일로 착석하여 진행되었다. 갱신 과제는 5 개의 연습 문 항을 통해 아동이 과제 수행 방법을 정확하게 숙지하도록 한 후, 본 문항을 실시하였다. 본 문항은 1단계부터 4 단계까지 순차적으로 진 행되었으며 정지 화면이 사라지기 전에 아동이 손가락으로 연습하 지 못하도록 통제하였다. 억제 과제는 각 단계마다 본 문항 실시 전, 5 개의 예시 자극이 주어져 연습을 통해 아동이 과제 수행 방법을 정확하게 숙지하도록 하였다. 연습 문항 및 본 문항 모두 1단계부터 3 단계까지 순차적으로 진행되었다. 전환 과제는 전환 이전 단계, 전 환 이후 단계, 심화 단계 순으로 진행되었으며, 전환 이전 단계와 심 화 단계 실시 전에는 각각 5 개의 연습 문항을 통해 아동이 과제 수 행 방법을 정확하게 숙지하도록 하였다. 아동이 직접 키보드의 ' $\mathrm{Z}$ ' (좌측자극 선택)와 '?'(우측자극 선택) 버튼을 눌러 반응하도록 하 였으며 각 버튼에는 아동이 보기 쉽도록 스티커를 붙여 실시하였 다. 또한 아동이 규칙을 따르지 않고 무작위로 버튼을 누르려 하는 경우, 검사자가 구어로 피드백을 제공하였다.

이야기 이해 과제는 소음이 없는 조용한 장소에서 아동과 검사 자가 일대일로 착석하여 진행되었다. 아동은 약 2 분 30 초간 이야기 만화를 시청한 후, 이야기 이해 질문에 답하도록 하였다. 이야기 만 화 시청 전, 아동에게 이야기 만화를 보는 동안 소리내지 않고 화면 을 집중하여 볼 것을 설명하였다. 시청 도중 소리를 내거나 집중하 지 않는 경우, 조용히 피드백을 제공하여 다시 이야기에 집중할 수 있도록하였다.

\section{자료분석}

한국 유아 사회성 기술 검사(Korean-Social Skill Rating Scale for Preschoolers, K-SSRSP; Yoon, 2012)의 채점은 검사 기관 사이 트를 통해 실시하였다. 각 문항마다 아동의 부모가 작성한 답안을 입력하여 각 영역별 원점수와 척도점수를 산출하였으며, 척도점수 (1-19점)를 영역별 수행력으로 사용하였다.

갱신 과제의 채점은 정반응한 문항에 1 점씩 부여하여 총점을 산 출하였으며 수행력으로 사용하였다. 억제 과제의 채점은 각 단계마 다 정반응한 자극에 1 점씩 부여하여 점수를 산출하였으며 3 단계의 점수를 수행력으로 사용하였다. 전환 과제의 채점은 E-prime 소프 
트웨어를 사용하여 아동이 반응을 할 때 정오 여부와 반응속도를 측정할 수 있도록 하였다. 이후, 각 단계마다 정확도(\%)와 평균 반 응속도 $(\mathrm{ms})$ 를 산출하였다. 본 연구에서는 전환 이후 단계의 정확 도를 백분율로 산출하여 수행력으로 사용하였다.

이야기 이해 과제의 채점은 채점 기준표에 따라 점수를 부여하 였다. 총 11 문항 중 4 문항은 정반응시 1 점으로 처리, 2 문항은 정반 응시 2 점으로 처리, 5 문항은 정반응시 채점 기준에 따라 1 점 혹은 2 점으로 처리되었다. 오반응한 문항은 0점으로 처리되었으며, 모든 문항을 정확하게 정반응하였을 시 총점은 18 점이었다. 본 연구는 아동의 총점을 산출하여 수행력으로 사용하였다.

\section{자료의 통계적 처리}

본 연구 자료의 모든 통계적 처리는 SPSS ver. 25 (SPSS Inc., Chicago, IL, USA)를 사용하여 실시하였다. 먼저 사회성 기술 검사에 서 사회성 기술 영역에 따른 집단 간 점수의 차이가 유의한지 알아 보기 위해 이원혼합분산분석(two-way mixed ANOVA)을 실시하 였다. 집행기능 과제(갱신 과제, 억제 과제, 전환 과제)에서 집단 간 수행력의 차이가 유의한지 알아보기 위해 각각 일원배치분산분석 (one-way ANOVA)을 실시하였다. 또한 이야기 이해 과제에서 집단 간 수행력의 차이가 유의한지 알아보기 위해 일원배치분산분석 (one-way ANOVA)을 실시하였다. 각 집단에서 사회성 기술 및 집 행기능과 이야기 이해 능력 간 유의한 상관관계가 나타나는지 살 펴보기 위해 Pearson 적률상관계수(Pearson correlation coefficient) 를 측정하였다. 또한 각 집단에서 사회성 기술 및 집행기능이 이야 기 이해 능력을 유의하게 예측할 수 있는지 알아보기 위해 단계적 중다회귀분석(stepwise multiple regression)을 실시하였다.

\section{연구결과}

\section{사회성 기술 영역(문제해결, 정서표현, 질서의식, 자신감)에 따른 집단 간 점수 차이}

사회성 기술 검사에서 집단 간 사회성 기술 영역에 따른 점수에

Table 2. Descriptive statistics of scores on K-SSRSP by groups

\begin{tabular}{lll}
\hline & SLI $(\mathrm{N}=14)$ & TD $(\mathrm{N}=19)$ \\
\hline Problem solving & $9.14(1.96)$ & $11.74(1.79)$ \\
Emotional expression & $8.93(1.59)$ & $13.16(2.48)$ \\
Sense of order & $9.14(2.71)$ & $11.68(2.75)$ \\
Confidence & $7.21(2.64)$ & $11.21(2.20)$ \\
\hline
\end{tabular}

Values are presented as mean (SD).

$\mathrm{SLI}=$ children with specific language impairment; $T D=$ typically developing children.
유의한 차이가 있는지 알아보기 위해 이원혼합분산분석을 실시한 결과, 집단 간 주효과가 통계적으로 유의하였다 $\left(F_{(1,31)}=32.979, p=\right.$ .000). 즉, 단순언어장애 아동의 점수 $(\mathrm{M}=8.61, \mathrm{SD}=2.22)$ 보다 일반 아동의 점수 $(\mathrm{M}=11.95, \mathrm{SD}=2.30)$ 가 유의하게 더 높은 것으로 나 타났다. 집단 내 요인으로 사회성 기술 영역에 관한 주효과가 통계적 으로 유의하게 나타났는데 $\left(F_{(3,93)}=5.480, p=.002\right)$, 정서표현 $(\mathrm{M}=$ $11.04, \mathrm{SD}=2.04)$, 문제해결 $(\mathrm{M}=10.44, \mathrm{SD}=1.87)$, 질서의식 $(\mathrm{M}=$ $10.41, \mathrm{SD}=2.73)$, 자신감 $(\mathrm{M}=9.21, \mathrm{SD}=2.42)$ 영역 순으로 점수가 크게 나타났다. 사회성 기술 영역과 집단에 따른 상호작용 효과는 통계적으로 유의하지 않았다 $\left(F_{(3,93)}=1.875, p=.139\right)$. 사회성 기술 영역에 따른 집단 간 점수에 대한 기술통계 결과는 Table 2, Figure 4에 제시하였다.

\section{집단 간 집행기능 과제에서의 수행력 차이}

갱신 과제: 매트릭스(Matrix)

집단 간 갱신 과제 수행 점수에 유의한 차이가 있는지 알아보기 위해 일원배치분산분석을 실시하였다. 분석 결과, 집단 간 수행 점 수의 차이가 통계적으로 유의하지 않았다 $\left(F_{(1,31)}=2.738, p=.108\right)$. 즉, 일반 아동 $(\mathrm{M}=10.11, \mathrm{SD}=3.35)$ 과 단순언어장애 아동 $(\mathrm{M}=8.14$, $\mathrm{SD}=3.39$ )은 갱신 과제의 수행에서 유의한 차이를 보이지 않았다.

\section{억제 과제: Fruit Stroop Task}

집단 간 억제 과제 수행 점수에 유의한 차이가 있는지 알아보기 위해 일원배치분산분석을 실시하였다. 분석 결과, 집단 간 수행 점 수의 차이가 통계적으로 유의하였다 $\left(F_{(1,31)}=11.035, p=.002\right)$. 즉, 억 제 과제에서 일반 아동의 수행 점수( $\mathrm{M}=21.53, \mathrm{SD}=5.85)$ 가 단순

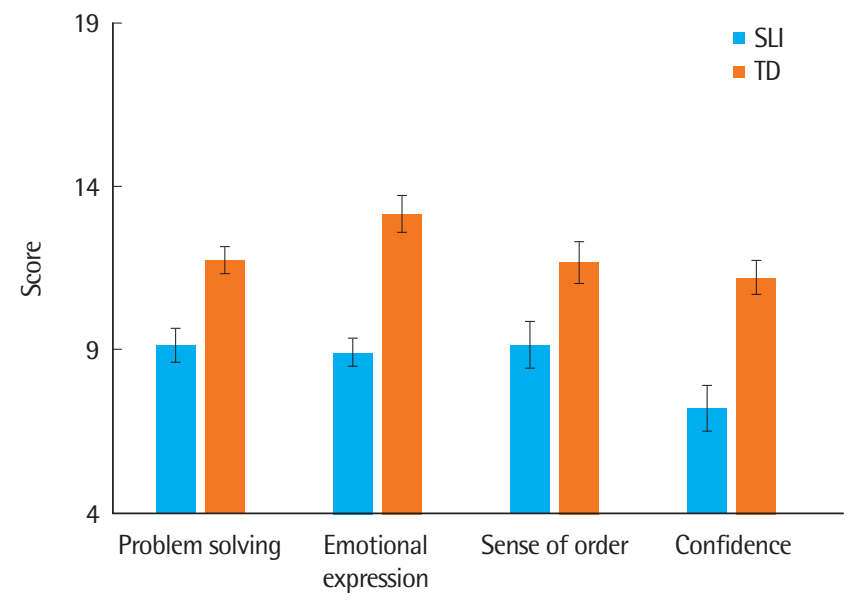

Figure 4. Scores of K-SSRSP by groups. $S L I=$ children with specific language impairment; TD=typically developing children. 
언어장애 아동의 수행 점수 $(\mathrm{M}=14.93, \mathrm{SD}=5.33)$ 에 비해 유의하게 높은 것으로 나타났다.

\section{전환 과제: 차원전환카드분류 과제(DCCS)}

집단 간 전환 과제 수행 정확도에 유의한 차이가 있는지 알아보 기 위해 일원배치분산분석을 실시하였다. 분석 결과, 집단 간 수행 정확도의 차이가 통계적으로 유의하였다 $\left(F_{(1,31)}=6.205, p=.018\right)$. 즉, 전환 과제에서 일반 아동의 수행 정확도 $(\mathrm{M}=83.33, \mathrm{SD}=22.22)$ 가 단순언어장애 아동의 수행 정확도 $(\mathrm{M}=57.14, \mathrm{SD}=37.96)$ 에 비 해 유의하게 높은 것으로 나타났다.

\section{집단 간 이야기 이해 과제에서의 수행력 차이}

집단 간 이야기 이해 과제 수행 점수에 유의한 차이가 있는지 알 아보기 위해 일원배치분산분석을 실시하였다. 분석 결과, 집단 간 수행 점수의 차이가 통계적으로 유의하였다 $\left(F_{(1,31)}=34.749, p=.000\right)$. 즉, 이야기 이해과제에서 일반아동의수행 점수 $(\mathrm{M}=12.79, \mathrm{SD}=2.49)$ 가 단순언어장애 아동의 수행 점수 $(\mathrm{M}=7.21, \mathrm{SD}=2.94)$ 에 비해 유 의하게 높았다.

\section{각 집단의 사회성 기술 및 집행기능과 이야기 이해 능력 간 상관관계}

일반 아동 집단에서의 각 변인 간 상관관계

일반 아동 집단의 사회성 기술(문제해결, 정서표현, 질서의식, 자 신감) 및 집행기능(갱신, 억제, 전환)과 이야기 이해 능력 간 상관관 계를 알아보기 위해 Pearson 적률상관계수를 측정하였다. 분석 결 과, 이야기 이해 과제 점수와 갱신 과제 점수 간 유의한 정적 상관관 계가 나타났다 $(r=.530, p=.020)$. 또한, 전환 과제의 정확도와 정서

Table 3. Correlation coefficient in TD group

\begin{tabular}{|c|c|c|c|c|c|c|c|}
\hline & $\begin{array}{l}\text { Problem } \\
\text { solving }^{\mathrm{a}}\end{array}$ & $\begin{array}{l}\text { Emo- } \\
\text { tional } \\
\text { expres- } \\
\text { sion }^{\mathrm{a}}\end{array}$ & $\begin{array}{l}\text { Sense } \\
\text { of } \\
\text { order }^{\mathrm{a}}\end{array}$ & $\begin{array}{l}\text { Confi- } \\
\text { dence }^{a}\end{array}$ & $\begin{array}{l}\text { Updat- } \\
\text { ing }^{\text {b }}\end{array}$ & $\begin{array}{l}\text { Inhibi- } \\
\text { tion }^{c}\end{array}$ & $\begin{array}{l}\text { Shift- } \\
\text { ing }^{d}\end{array}$ \\
\hline Emotional expression $^{a}$ & $.561^{*}$ & & & & & & \\
\hline Sense of order ${ }^{\mathrm{a}}$ & $.592^{* *}$ & .163 & & & & & \\
\hline Confidence $^{a}$ & $.508^{*}$ & $.707^{* * *}$ & -.016 & & & & \\
\hline Updating $^{\mathrm{b}}$ & .237 & .373 & .221 & .321 & & & \\
\hline Inhibition $^{c}$ & .056 & .342 & .007 & .021 & $.674^{* *}$ & & \\
\hline Shifting $^{\mathrm{d}}$ & .349 & $.538^{*}$ & .364 & .189 & .286 & .313 & \\
\hline Story comprehension & -.200 & .141 & -.018 & .212 & $.530^{*}$ & .298 & -.084 \\
\hline
\end{tabular}

$\mathrm{TD}=$ typically developing children.

a'Korean-Social Skill Rating Scale for Preschoolers (K-SSRSP; Yoon, 2012), ' Matrix, "Fruit Stroop task, 'DCCS.

${ }^{*} p<.05,{ }^{* *} p<.01,{ }^{* * *} p \leq .001$.
표현 점수 간 유의한 정적 상관이 있었다 $(r=.538, p=.017)$. 사회성 기술 내에서 문제해결 점수는 정서표현 $(r=.561, p=.012)$, 질서의식 $(r=.592, p=.008)$, 자신감 $(r=.508, p=.026)$ 점수와 유의한 정적 상 관이 나타났으며, 정서표현 점수는 자신감 점수 $(r=.707, p=.001)$ 와 유의한 정적 상관관계를 보였다. 집행기능 내에서는 갱신 과제 점수 와 억제 과제 점수 간 유의한 정적 상관관계가 나타났다 $(r=.674$, $p=.002)$. 자세한 결과는 Table 3에 제시하였다.

\section{단순언어장애 아동 집단에서의 각 변인 간 상관관계}

단순언어장애 아동 집단의 사회성 기술(문제해결, 정서표현, 질 서의식, 자신감) 및 집행기능(갱신, 억제, 전환)과 이야기 이해 능력 간 상관관계를 알아보기 위해 Pearson 적률상관계수를 측정하였 다. 분석 결과, 이야기 이해 과제 점수는 문제해결 $(r=.810, p=.000)$, 정서표현 $(r=.579, p=.030)$ 점수와 유의한 정적 상관관계가 나타났 다. 전환 과제의 정확도는 문제해결 $(r=.572, p=.032)$, 질서의식 $(r=$ $.686, p=.007)$ 점수와 유의한 정적 상관을 보였다. 또한 사회성 기 술 내에서 문제해결 점수는 질서의식 점수와 유의한 정적 상관을 보였으며 $(r=.576, p=.031)$ 집행기능 내에서는 갱신 과제 점수와 억 제 과제 점수간 유의한 정적 상관관계가 나타났다 $(r=.775, p=.001)$. 자세한 결과는 Table 4에 제시하였다.

\section{각 집단의 이야기 이해 능력에 대한 사회성 기술 및 집행기능의 예측력}

각 집단의 이야기 이해 능력을 예측하는 요인이 무엇인지 알아보 기 위해 단계적 중다회귀분석을 실시하였다. 독립변인으로 사회성 기술 영역별(문제해결, 정서표현, 질서의식, 자신감) 점수와 집행기 능 과제 수행력(갱신 과제 점수, 억제 과제 점수, 전환 과제 정확도)

Table 4. Correlation coefficient in SLI group

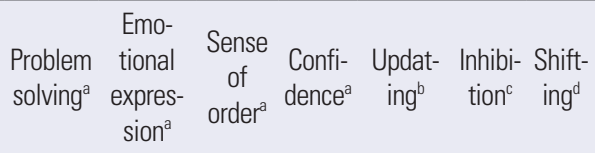

\begin{tabular}{lllllllllll}
\hline Emotional expression $^{\mathrm{a}}$ & .275 & & & & & & \\
Sense of order $^{\mathrm{a}}$ & $.576^{*}$ & .181 & & & & & \\
Confidence $^{\mathrm{a}}$ & .202 & .462 & .275 & & & & \\
Updating $^{\mathrm{b}}$ & .391 & .144 & .323 & -.167 & & & \\
Inhibition $^{\mathrm{c}}$ & .016 & .208 & .267 & -.327 & $.775^{* * *}$ & & \\
Shifting $^{\mathrm{d}}$ & $.572^{*}$ & -.139 & $.686^{* *}$ & -.081 & .290 & .199 & \\
Story comprehension & $.810^{* * *}$ & $.579^{*}$ & .449 & .291 & .228 & .026 & .318 \\
\hline
\end{tabular}

$\mathrm{SLI}=$ children with specific language impairment.

aKorean-Social Skill Rating Scale for Preschoolers (K-SSRSP; Yoon, 2012), ' Matrix, 'Fruit Stroop task, ${ }^{\circ} D C C S$.

${ }^{*} p<.05,{ }^{* *} p<.01,{ }^{* * *} p \leq .001$. 
의 7가지 변수를 입력하여 분석하였다.

분석 결과, 일반 아동 집단의 이야기 이해 과제 점수를 예측해주 는 요인은 갱신 과제 점수로 나타났다 $\left(F_{(1,17)}=6.651, p=.020\right.$, 수정된 $\left.\mathrm{R}^{2}=.239\right)$. 즉, 갱신 능력이 일반 아동의 이야기 이해 능력을 $23.9 \%$ 예측해주는 것으로 나타났다. 한편, 단순언어장애 아동 집단의 이 야기 이해 과제 점수를 예측해주는 요인은 문제해결과 정서표현 점 수로 나타났다. 즉, 1 단계 분석에서 문제해결 능력이 단순언어장애 아동의 이야기 이해 능력을 $62.8 \%$ 예측해주는 것으로 나타났으며 $\left(F_{(1,12)}=22.968, p=.000\right.$, 수정된 $\left.\mathrm{R}^{2}=.628\right), 2$ 단계 분석에서 정서표 현 능력이 $12.8 \%$ 의 설명력을 더해 이야기 이해 능력을 $75.6 \%$ 예측 하는 것으로 나타났다 $\left(F_{(2,1)}=21.169, p=.000\right.$, 수정된 $\left.\mathrm{R}^{2}=.756\right)$.

\section{논의 및 결론}

본 연구에서는 단순언어장애 아동과 일반 아동의 사회성 기술, 집행기능, 이야기 이해 능력을 비교하고자 하였다. 또한, 각 집단에 서 사회성 기술 및 집행기능과 이야기 이해 능력 간 상관관계를 확 인하고, 이야기 이해 능력에 대한 사회성 기술과 집행기능의 예측 력을 확인하고자 하였다.

연구 결과, 사회성 기술 검사에서 집단을 살펴보았을 때 단순언 어장애 아동이 일반 아동보다 유의하게 낮은 사회성 기술을 보였 다. 이는 언어에 어려움이 있는 아동에게서 사회적 어려움이 발견 되었다는 선행연구(Beitchman, Hood, Rochon, \& Peterson, 1989; Cantwell, Baker, \& Mattison, 1981; Lindsay et al., 2007)와 일치하 는 결과이다. 또한, Redmond와 Rice (2002)는 단순언어장애 아동 이 5세에서 7세 사이에 사회성 문제를 지속적으로 보였다고 하였 다. 즉, 본 연구의 결과는 단순언어장애 아동이 언어의 어려움뿐만 아니라 사회성이라는 영역에서도 어려움을 겪을 수 있다는 가능성 을 보여준다.

사회성 기술 영역의 경우, 정서표현, 문제해결, 질서의식, 자신감 영역 순으로 점수가 높은 것으로 나타났으며, 집단과 사회성 기술 영역에 따른 상호작용은 유의하지 않았다. 하지만 이에 대한 그래 프인 Figure 4에서, 일반 아동의 경우 다른 영역에 비해 정서표현의 점수가 높고 단순언어장애 아동의 경우 다른 영역에 비해 자신감의 점수가 낮아 집단 간 격차가 커지는 경향성을 확인하였다. 정서적 유능성은 생애 초 영유아기부터 상대방의 표정을 지각하고 분류하 면서 발달하기 시작하는데(Field, Woodson, Greenberg, \& Cohen, 1982), 언어를 습득하는 초기 단계에는 아동이 경험하는 정서에 대 한 표현이 언어와 통합되지 못하다가(Bloom, 1993), 점차 언어발달 이 이뤄지면서 아동은 자신의 정서에 대해 말과 언어로 표현할 수
있게 된다(Domitrovich, Cortes, \& Greenberg, 2007; Izard et al., 2008). 일반 아동의 경우, 생애 초기부터 경험하지만 비언어적인 수 단으로 전달하던 정서를 언어발달이 적절하게 진행됨에 따라 상대 방에게 말과 언어로 정확하게 표현할 수 있게 된 것으로 해석할 수 있다. 한편, Durkin 등(2017)은 아동의 언어적 결함이 사회적 상황 으로부터의 회피로 이어질 수 있다고 하였으며, Redmond와 Rice (1998)는 언어발달에 어려움을 겪는 아동들이 자신의 언어적 결함 을 인식하고 사회적 상황에서 철수할 가능성을 언급하였다. 이처럼 단순언어장애 아동의 자신감이 특히 낮은 결과는 자신의 언어적 어려움을 스스로 느끼는 것과 연관되어 있을 것으로 해석할 수 있 다. 즉, 단순언어장애 아동은 자신의 언어능력이 또래에 비해 지체 된 것을 인식함으로써 자신감이 결여된 것으로 분석된다.

이처럼 단순언어장애 아동의 낮은 자신감 점수는 집단 간 주효 과가 유의한 데에 기여했을 가능성이 있다. 그러나 단순언어장애 아동의 자신감 점수는 이야기 이해 과제 수행력과 상관이 유의하 지 않았으며, 이야기 이해 과제 수행력을 예측해주지 않는 것으로 나타났다. 이에 관해 아동의 사회성 기술을 부모의 보고로 측정함 으로써 이러한 결과가 나타났을 가능성도 고려해볼 수 있다. 즉, 단 순언어장애 아동의 부모가 느끼는 자녀의 자신감 결여가 실제로 자녀의 자신감이 부족한 정도보다 더 컸을 수 있으며, 또는 아동이 아닌 부모의 자신감이 결여된 것이 검사 시 반영되어 마치 단순언 어장애 아동의 자신감이 매우 낮은 것처럼 결과가 나타난 것으로 해석할 수 있다.

두번째로, 두 집단 간 집행기능을 비교한 결과, 억제 과제에서 단 순언어장애 아동이 일반 아동보다 유의하게 낮은 수행력을 보였다. 이는 단순언어장애 아동이 언어적 억제 과제에서 또래 일반 아동에 비해 유의하게 낮은 수행력을 보였다는 선행연구(Kapa et al., 2017) 와 일치하는 결과이다. Spaulding (2010)의 연구에서도 방해자극 에 대한 반응을 억제해야 하는 과제를 통해 단순언어장애 아동과 일반 아동의 억제 능력을 비교하였을 때, 단순언어장애 아동이 더 낮은 수행력을 보였다. 또한 본 연구의 단순언어장애 아동은 전환 과제에서도 일반 아동보다 수행력이 유의하게 낮은 것으로 나타났 다. 이는 자극이 변경될 때 주의를 전환하여 반응해야 하는 과제에 서 단순언어장애 아동이 일반 아동보다 더 낮은 정확도를 보였다 는 선행연구(Im-Bolter, Johnson, \& Pascual-Leone, 2006)와 일치 하는 결과이다. 또한 단순언어장애 아동이 일반 아동에 비해 유의 하게 낮은 비언어적 전환 능력을 보였다는 선행연구(Kapa et al., 2017)의 결과를 지지한다. 즉, 본 연구의 결과는 단순언어장애 아동 이 목표지향적인 행동을 위해 주의를 억제하고 전환하는데 어려움 이 있음을 의미한다. 한편, 갱신 과제에서는 집단 간 수행력의 차이 
가 유의하지 않았다. 이는 비언어적 갱신 과제에서 단순언어장애 아동이 일반 아동과 유의한 수행력의 차이를 보이지 않는다는 선 행연구(Yim et al., 2015)의 결과를 뒷받침하며, 단순언어장애 아동 의 비언어적 갱신 능력이 다른 하위 기능들에 비해 비교적 손상되 지 않았음을 보여준다.

세번째로, 두 집단 간 이야기 이해 능력을 비교한 결과, 단순언어 장애 아동의 수행력이 일반 아동의 수행력보다 유의하게 낮은 것으 로 나타났다. 이는 단순언어장애 아동들이 또래 일반 아동에 비해 낮은 이야기 이해 능력을 가진다는 선행연구(Liles, Duffy, Merritt, \& Purcell, 1995; Merritt \& Liles, 1987)를 지지하는 결과이다. 또한, Yim과 Park 등(2019)의 연구에서도 삽화를 보며 이야기 들은 후, 이야기 이해 질문에 답하는 과제에서 만 4-6세 언어발달지연 아동 들이 또래 일반 아동보다 유의하게 낮은 이야기 이해 능력을 보였 다. Botting과 Adams (2005) 그리고 Ford와 Milosky (2008)에 따르 면, 단순언어장애 아동은 이야기 내의 사실적인 정보를 이해하고 기억하는 것과 이를 통해 표면적으로 노출되지 않은 정보에 관해 추론하는 것 모두에서 어려움을 보인다. 이는 단순언어장애 아동 들이 이야기에서 제시된 정보들을 통합하는데 어려움을 겪는 것과 관련된 것으로 보인다(Bishop \& Adams, 1992; Norbury \& Bishop, 2002). 즉, 단순언어장애 아동은 이야기에서 구어로 제시된 어휘나 문장에 대한 이해가 어려웠을 수 있으며, 이에 더해 시청각적으로 드러난 정보에 관한 회상, 정보의 분류 및 통합, 숨겨진 정보에 관한 추론 능력 등에 결함이 있어 이를 종합적으로 요구하는 이야기 이 해 과제에서의 수행력이 일반 아동에 비해 낮은 것으로 해석할 수 있다.

네번째로, 각 집단에서 사회성 기술, 집행기능, 이야기 이해 능력 간의 관계를 살펴본 결과, 일반 아동의 이야기 이해 능력은 갱신 능 력과 유의한 정적 상관이 있었다. 이는 일반 아동의 경우, 갱신 능력 이 높을수록 이야기 이해 능력이 높았다는 것을 보여준다. 이야기 이해 질문에 적절히 반응하기 위해서는 일차적으로 이야기 속에 등장한 인물, 사건 등에 대한 정보를 정확히 기억하고 회상할 수 있 어야 하므로, 기억 속에 정보를 저장하고 새로운 정보가 유입될 시 이를 심적으로 조작 및 수정할 수 있는 갱신 능력이 이와 연관되어 있는 것으로 해석할 수 있다. 그러나 갱신 능력 외에 다른 집행기능 이나 사회성 기술은 이야기 이해 능력과 상관이 유의하지 않아, 연 관성이 없음을 보여준다. 한편, 단순언어장애 아동의 이야기 이해 능력은 사회성 기술 중 문제해결, 정서표현과 유의한 정적 상관을 보였다. 즉, 단순언어장애 아동은 문제해결과 정서표현을 잘 할수 록 이야기 이해 과제 수행력이 높았다. 이러한 결과는 단순언어장 애 아동의 경우 이야기 속의 사건과 인물의 감정을 파악하고, 발생
한 문제를 해결하는 능력이 이야기 이해 질문에 적절하게 반응하 는 것과 연관이 있음을 보여준다. 하지만 사회성 기술 중 질서의식, 자신감 영역과 집행기능은 이야기 이해 능력과 상관이 유의하지 않아 연관성이 없음을 확인하였다.

한편, 일반 아동의 전환 능력은 사회성 기술 중 정서표현과 유의 한 정적 상관이 있었으며, 단순언어장애 아동의 전환 능력은 문제 해결, 질서의식 영역과 정적 상관이 유의하였다. 이는 일반 아동의 경우 전환 능력이 높을수록 정서표현을 잘하며, 단순언어장애 아 동의 경우 전환 능력이 높을수록 문제해결, 질서의식 능력이 높음 을 보여준다. 즉, 동일한 전환 능력일지라도 이와 관련이 있는 사회 성 기술의 영역이 집단별로 다르게 나타나 양상의 차이가 있음을 보여준다. 그러나 일반 아동과 단순언어장애 아동 모두 집행기능 중 전환 능력만 사회성 기술과 연관성이 있음을 확인하였다. 이는 전환 능력이 사회적인 상황에서 다양한 방식으로 생각하는 것을 도와(Bonino \& Cattelino, 1999) 상황에 맞게 사회성 기술을 사용 하는 것과 관련이 있는 것으로 해석할 수 있으며, 갱신 능력이나 억 제 능력은 이와 연관성이 낮은 것으로 보인다. 또한, 두 집단 모두 자 신감 영역은 어느 집행기능과도 상관이 유의하지 않아 아동이 자 신의 의사를 떳떳하게 전달하고 침착하게 대응하는 등 자기 확신 에 찬 태도를 보이는 것은 집행기능과 연관성이 낮은 것으로 분석 된다.

사회성 기술 내에서 일반 아동은 문제해결과 정서표현, 질서의 식, 자신감 간, 정서표현과 자신감 간 유의한 정적 상관이 있는 것으 로 나타났으며, 단순언어장애 아동은 문제해결과 질서의식 간 유의 한 정적 상관을 보였다. 즉, 일반 아동의 경우 질서의식과 정서표현, 자신감 간의 관계를 제외한 모든 사회성 기술 영역들 간의 연관성 이 나타나 각 영역들 간의 연결고리가 형성되어 있는 것으로 보인 다. 반면, 단순언어장애 아동의 경우 문제해결과 질서의식만 서로 관련이 있어, 전반적으로 사회성 기술 영역들이 서로 효율적으로 도움을 주지 못하며 분리되어 발달하는 것으로 보인다. 집행기능 내에서는 두 집단 모두 갱신 능력과 억제 능력 간 정적 상관이 유의 하였으며, 전환 능력은 갱신 능력 및 억제 능력과 상관이 유의하지 않았다. 이는 갱신 능력과 억제 능력 간에만 연관성이 있음을 보여 주는데, 이러한 결과는 집행기능의 하위 기능들이 낮은 상관관계 를 보일 수 있다는 선행연구(Friedman, 2016)의 주장을 뒷받침하 며, 집행기능 측정 시 하위 기능들을 전반적으로 평가해야 할 필요 성을 보여준다.

마지막으로 각 집단의 이야기 이해 능력을 예측해주는 요인이 무 엇인지 분석한 결과, 일반 아동의 이야기 이해 능력은 갱신 능력이 $23.9 \%$ 예측해주는 것으로 나타났다. 이는 이야기를 이해하기 위해 
서는 인물, 사건 등 이야기 속에서 연속적으로 주어지는 정보들을 갱신할 수 있어야 한다는 Whitely와 Colozzo (2013)의 주장을 지지 한다. 특히 본 연구의 이야기 이해 과제에서 참조적 이해 질문의 경 우, 이야기에서 노출된 정보를 그대로 산출해야 하기 때문에 갱신 능력이 직접적으로 영향을 미쳤을 가능성이 있다. 또한, 추론적 이 해 질문의 경우에도 일차적으로 주어진 정보를 기억 속에 정확히 저장해야 그것을 바탕으로 추론할 수 있기 때문에 갱신 능력이 중 요하게 작용한 것으로 해석할 수 있다. 본 연구의 결과는 일반 아동 의 이야기 이해 과정에는 갱신 능력이 중요한 영향을 미쳐 갱신 능 력을 효율적으로 사용한 아동이 이야기 이해를 더 잘 한다는 것을 보여준다.

반면, 단순언어장애 아동의 경우, 사회성 기술 중 문제해결이 이 야기 이해 능력을 $62.8 \%$ 예측하는 것으로 나타났으며, 이에 정서표 현이 $12.8 \%$ 의 설명력을 더해 $75.6 \%$ 예측하는 것으로 나타났다. 즉, 단순언어장애 아동의 이야기 이해 능력을 가장 잘 설명해주는 요 인은 문제해결로 나타났으며, 이에 추가적으로 정서표현이 설명력 을 더했다. 본 연구에서 사용한 과제의 이야기 속에는 인물들 간의 갈등, 감정 변화 등이 포함되는데, 단순언어장애 아동의 경우 실제 사회적인 상황에서 문제 발생 시 적절한 전략을 사용하고 상황에 맞는 정서를 정확하게 표현하는 능력이 이야기 내용을 이해하는데 중요하게 작용한 것으로 해석할 수 있다. 특히, 앞에서 언급한 바와 같이 단순언어장애 아동의 문제해결 능력은 집행기능 중 전환 능 력과도 상관이 유의하였는데, 그럼에도 불구하고 이들의 이야기 이 해 능력을 유의하게 예측해주는 집행기능이 나타나지 않은 결과로 보아 이야기를 적절하게 이해하는데 문제해결 능력이 매우 중요하 게 작용하는 것으로 분석된다.

또한, 본 연구에서는 이야기 이해 과정이 단어, 구, 문장의 의미 및 구문에 대한 파악(Daneman \& Merikle, 1996), 이야기 속 정보 와 기존 지식을 바탕으로 한 추론(Chae, 2001) 등을 요구하며, 아동 의 언어능력을 반영 및 예측한다는(Khan et al., 2016) 선행연구의 결과를 참고하여 이야기 이해 능력을 하나의 대표적인 언어능력으 로 측정하였다. Stevens와 Bliss (1995)는 단순언어장애 아동이 문 제를 해결하기 위한 전략 사용에 어려움이 있다고 하였으며, Marton 등(2005)의 연구에서는 단순언어장애 아동이 갈등 상황에서 수동적으로 반응한다고 보고하였다. 또한, 많은 선행연구들을 통 해 발달 초기 아동의 정서표현 능력과 언어능력 간의 정적 상관이 밝혀졌으며(Dixon \& Shore, 1997; Dixon \& Smith, 2000), 단순언어 장애 아동은 일반 아동에 비해 정서를 조절하거나(Fujiki, Brinton, \& Clarke, 2002) 감정을 추론하는 능력이 더 낮다고 밝혀졌다(Ford \& Milosky, 2003). 즉, 단순언어장애 아동의 낮은 언어능력과 문제
해결 및 정서표현의 어려움은 관련이 있는 것으로 보인다. 이에 본 연구 결과를 더해 단순언어장애 아동이 보이는 문제해결 및 정서표 현의 어려움이 이들의 언어 습득을 제한하고 있을 가능성을 제시 해볼 수 있다. 따라서, 단순언어장애 아동의 사회성 기술 중 문제해 결 및 정서표현에 관한 훈련이 언어능력 증진에 도움을 줄 수 있을 것으로 보인다.

또한, 앞에서 단순언어장애 아동의 갱신 능력은 일반 아동과 유 의한 차이가 없는 것으로 나타났는데, 일반 아동과 달리 단순언어 장애 아동의 이야기 이해 능력은 갱신 능력이 예측해주지 않는 것 으로 나타났다. 이는 집행기능의 다른 하위 기능에 비해 비교적 덜 손상된 것으로 나타난 갱신 능력을 단순언어장애 아동이 효율적 으로 사용하지 못하고 있음을 보여준다. 따라서, 단순언어장애 아 동이 갱신 능력을 충분히 활용할 수 있도록 훈련한다면 언어 습득 에 도움이 될 것으로 분석된다.

\section{REFERENCES}

Alduncin, N., Huffman, L. C., Feldman, H. M., \& Loe, I. M. (2014). Executive function is associated with social competence in preschool-aged children born preterm or full term. Early Human Development, 90(6), 299306.

Alisinanoğlu, F., \& Kesicioğlu, O. S. (2010). The research on the behavioral problems of preschoolers in terms of various variables (Giresun sampling). Theoretical Education Science, 3(1), 93-110.

Alpan, Y. (2006). Adapting social and emotional assessment tool for 12-36 months old babies and children to Turkish children (Master's thesis). Gazi University, Ankara, Turkey.

Beitchman, J. H., Hood, J., Rochon, J., \& Peterson, M. (1989). Empirical classification of speech/language impairment in children II. Behavioral characteristics. Journal of American Academy of Child and Adolescent Psychiatry, 28(1), 118-123.

Bishop, D. V. M., \& Adams, C. (1992). Comprehension problems in children with specific language impairment: literal and inferential meaning. Journal of Speech and Hearing Research, 35(1), 119-129.

Bloom, L. (1993). The transition from infancy to language. New York: Cambridge University Press.

Bonino, S., \& Cattelino, E. (1999). The relationship between cognitive abilities and social abilities in childhood: a research on flexibility in thinking and cooperation with peers. International Journal of Behavioral Development, 23(1), 19-36. 
Boone, R. T., \& Cunningham, J. G. (1998). Children's decoding of emotion in expressive body movement: the development of cue attunement. Developmental Psychology, 34(5), 1007-1016.

Botting, N., \& Adams, C. (2005). Semantic and inferencing abilities in children with communication disorders. International Journal of Language \& Communication Disorders, 40(1), 49-66.

Brinton, B., Fujiki, M., \& McKee, L. (1998). Negotiation skills of children with specific language impairment. Journal of Speech Language and Hearing Research, 41(4), 927-940.

Brownell, C., \& Brown, E. (1992). Peers and play in infants and toddlers. In V. Van Hasselt \& M. Hersen (Eds.), Handbook of social development (pp. 183-200). NY: Plenum.

Bruner, J. S., \& Sherwood, V. (1976). Peek-a-boo and the learning of rule structures. In J. S. Bruner, A. Jolly, \& K. Sylva (eds.), Play: Its role in development and evolution (pp. 277-285). Hammandsworth, England: Penguin.

Cantwell, D. P., Baker, L., \& Mattison, R. (1981). Prevalence, type and correlates of psychiatric diagnoses in 200 children with communication disorder. Developmental and Behavioral Pediatrics, 2(4), 131-136.

Chae, J. O. (2001). Assessment of children's story comprehension: a review of research. Korean Journal of Child Studies, 22(1), 227-240.

Cho, Y. J., \& Yim, D. S. (2020). A comparative study of chunking skills in bilingual children and monolingual children with and without specific language impairment. Communication Sciences and Disorders, 25(2), 242257.

Cock, E. S., Henrichs, J., Klimstra, T. A., Maas, A. J., Vreeswijk, C. M., Meeus, W. H., \& Bakel, H. J. (2017). Longitudinal associations between parental bonding, parenting stress, and executive functioning in toddlerhood. Journal of Child and Family Studies, 26(6), 1723-1733.

Cole, P. M., Martin, S. E., \& Dennis, T. A. (2004). Emotion regulation as a scientific construct: methodological challenges and directions for child development research. Child Development, 75(2), 317-333.

Collisson, B. A., Grela, B., Spaulding, T., Rueckl, J. G., \& Magnuson, J. S. (2015). Individual differences in the shape bias in preschool children with specific language impairment and typical language development: theoretical and clinical implications. Developmental Science, 18(3), 373-388.

Conti-Ramsden, G., \& Botting, N. (2004). Social difficulties and victimization in children with SLI at 11 years of age. Journal of Speech, Language, and Hearing Research, 47(1), 145-161.

Coplan, R. J., Closson, L., \& Arbeau, K. (2007). Gender differences in the behavioral associates of loneliness and social dissatisfaction in kindergarten.
The Journal of Child Psychology and Psychiatry, 48(10), 988-995.

Corsaro, W. A. (1988). Peer culture in the preschool. Theory into Practice, $27(1), 19-24$.

Crais, E. R., \& Chapman, R. S. (1987). Story recall and inferencing skills in language/learning-disabled and nondisabled children. Journal of Speech and Hearing Disorders, 52(1), 50-55.

Daneman, M., \& Merikle, P. (1996). Working memory and language comprehension: a meta-analysis. Psychonomic Bulletin \& Review, 3(4), 422-433.

Denham, S. A., \& Zoller, D. (1991). "When my hamster died, I cried": preschoolers' attributions of the causes of emotions. The Journal of Genetic Psychology, 152(3), 371-373.

Desmarais, C., Nadeau, L., Trudeau, N., Filiatrault-Veilleux, P., \& Maxès-Fournier, C. (2013). Intervention for improving comprehension in 4-6 years old children with specific language impairment: practicing inferencing is a good thing. Clinical Linguistics \& Phonetics, 27(6-7), 540-552.

Diamond, A. (2006). The early development of executive functions. In E. Bialystock \& F. I. M. Craik (Eds.), Lifespan cognition: mechanisms of change (pp. 70-95). Oxford, England: Oxford University Press.

Diamond, A. (2013). Executive functions. Annual Review of Psychology, 64(1), 135-168.

Dixon, W. E., \& Shore, C. (1997). Temperamental predictors of linguistic style during multiword acquisition. Infant Behavior \& Development, 20(1), 99103.

Dixon, W. E., \& Smith, P. H. (2000). Links between early temperament and language acquisition. Merrill-Palmer Quarterly, 46(3), 417-440.

Domitrovich, C. E., Cortes, R. C., \& Greenberg, M. T. (2007). Improving young children's social and emotional competence: A randomized trial of the preschool "PATHS" curriculum. Journal of Primary Prevention, 28(2), 6791.

Durkin, K., Toseeb, U., Botting, N., Pickles, A., \& Conti-Ramsden, G. (2017). Social confidence in early adulthood among young people with and without a history of language impairment. Journal of Speech, Language, and Hearing Research, 60(6), 1635-1647.

Eisenberg, N., Fabes, R. A., Guthrie, I. K., \& Reiser, M. (2000). Dispositional emotionality and regulation: their role in predicting quality of social functioning. Journal of Personality and Social Psychology, 78(1), 136-157.

Elliott, S. N., \& Busse, R. (2004). Assessment and evaluation of students' behavior and intervention outcomes: the utility of rating scale methods. In R. Rutherford, M. Quinn, \& S. Mathur (Eds.), Handbook of research in emotional and behavioral disorders (pp. 123-142). New York (NY): Guilford 
Press.

Ellis, S., \& Siegler, R. S. (1994). Development of problem solving. In R. J. Sternberg (Ed.), Thinking and problem solving. Handbook of perception and cognition (2nd ed., pp. 333-367). San Diego, CA: Academic Press.

Field, T. M., Woodson, R., Greenberg, R., \& Cohen, D. (1982). Discrimination and imitation of facial expressions by neonates. Science, 218(4568), 179-181.

Filiatrault-Veilleux, P., Bouchard, C., Trudeau, N., \& Desmarais, C. (2016). Comprehension of inferences in a narrative in 3-to 6-year-old children. Journal of Speech, Language, and Hearing Research, 59(5), 1099-1110.

Ford, J. A., \& Milosky, L. M. (2003). Inferring emotional reactions in social situations: differences in children with language impairment. Journal of Speech, Language, and Hearing Research, 46(1), 21-30.

Ford, J. A., \& Milosky, L. M. (2008). Inference generation during discourse and its relation to social competence: an online investigation of abilities of children with and without language impairment. Journal of Speech, Language, and Hearing Research, 51(2), 367-380.

Freedle, R. O. (1979). New directions in discourse processing. Norwood, NJ: Ablex Publishing.

Friedman, N. P. (2016). Research on individual differences in executive functions. Linguistic Approaches to Bilingualism, 6(5), 535-548.

Fujiki, M., Brinton, B., \& Clarke, D. (2002). Emotion regulation in children with specific language impairment. Language, Speech, and Hearing Services in Schools, 33(2), 102-111.

Fujiki, M., Brinton, B., Isaacson, T., \& Summers, C. (2001). Social behaviors of children with language impairment on the playground: a pilot study. Language, Speech, and Hearing Services in Schools, 32(2), 101-113.

Fujiki, M., Brinton, B., \& Todd, C. M. (1996). Social skills of children with specific language impairment. Language, Speech, and Hearing Services in Schools, 27(3), 195-202.

Gathercole, S. E., \& Baddeley, A. D. (1990). Phonological memory deficits in language disordered children: is there a causal connection?. Journal of Memory and Language, 29(3), 336-360.

Gertner, B. L., Rice, M. L., \& Hadley, P. A. (1994). Influence of communicative competence on peer preferences in a preschool classroom. Journal of Speech, Language, and Hearing Research, 37(4), 913-923.

Graybeal, C. (1981). Memory for stories in language-impaired children. Applied Psycholinguistics, 2(3), 269-283.

Gresham, F. M. (2002). Social skills assessment and instruction for students with emotional and behavioral disorders. In K. L. Lane, F. M. Gresham, \& T.
E. O'Shaughnessy (Eds.), Intervention for children with or at risk for emotional and behavioral disorders (pp. 242-258). Boston: Allyn \& Bacon.

Gresham, F. M., \& Elliott, S. N. (1990). Social skills rating system. Minneapolis, MN: Pearson Assessments.

Gresham, F. M., \& Elliott, S. N. (2008). Social skills improvement system: rating scales manual. Minneapolis, MN: Pearson Assessments.

Gülay, H., \& Akman, B. (2009). Social skills in the preschool stage. Ankara: PegemA.

Harris, P. (1989). Children and emotion. Blackwell: Oxford.

Hart, K. I., Fujiki, M., Brinton, B., \& Hart, C. H. (2004). The relationship between social behavior and severity of language impairment. Journal of Speech, Language and Hearing Research, 47(3), 647-662.

Hecke, A. V., Mundy, P. C., Acra, C. F., Block, J. J., Delgado, C. E., Parlade, M. V., Meyer, J. A., Neal, A. R., \& Pomares, Y. B. (2007). Infant joint attention, temperament, and social competence in preschool children. Child Development, 78(1), 53-69.

Howes, C. (1988). Peer interaction in young children. Monographs of the Society for Research in Child Development, 53(2), 1-92.

Hughes, C. (1998). Executive function in preschoolers: links with theory of mind and verbal ability. British Journal of Developmental Psychology, 16(2), 233-253.

Huyder, V., \& Nilsen, E. S. (2012). A dyadic data analysis of executive functioning and children socially competent behaviours. Journal of Applied Developmental Psychology, 33(4), 197-208.

Im-Bolter, N., Johnson, J., \& Pascual-Leone, J. (2006). Processing limitations in children with specific language impairment: the role of executive function. Child Development, 77(6), 1822-1841.

Izard, C., Fine, S., Schultz, D., Mostow, A., Ackerman, B., \& Youngstrom, E. (2001). Emotion knowledge as a predictor of social behavior and academic competence in children at risk. Psychological Science, 12(1), 18-23.

Izard, C. E., King, K. A., Trentacosta, C. J., Morgan, J. K., Laurenceau, J., Krauthamer-Ewing, E. S., \& Finlon, K. J. (2008). Accelerating the development of emotion competence in Head Start children: effects on maladaptive behavior. Development \& Psychopathology, 20(1), 369-397.

Jamison, K. R., Forston, L. D., \& Stanton-Chapman, T. L. (2012). Encouraging social skill development through play in early childhood special education classrooms. Young Exceptional Children, 15(2), 3-19.

Kapa, L. L., \& Plante, E. (2015). Executive function in SLI: recent advances and future directions. Current Developmental Disorders Reports, 2(3), 245252. 
Kapa, L. L., Plante, E., \& Doubleday, K. (2017). Applying an integrative framework of executive function to preschoolers with specific language impairment. Journal of Speech, Language, and Hearing Research, 60(8), 2170-2184.

Karg1, E., \& Erkan, S. (2004). An investigation of preschool children's problem behaviors (Ankara sample). Journal of Hacettepe University Faculty of Education, 27, 135-144.

Kendeou, P., van den Broek, P., White, M. J., \& Lynch, J. (2009). Predicting reading comprehension in early elementary school: the independent contributions of oral language and decoding skills. Journal of Educational Psychology, 101(4), 765-778.

Key-DeLyria, S. E., \& Altmann, L. J. P. (2016). Executive function and ambiguous sentence comprehension. American Journal of Speech- Language Pathology, 25(2), 252-267.

Khan, K. S., Gugiu, M. R., Justice, L. M., Bowles, R. P., Skibbe, L. E., \& Piasta, S. B. (2016). Age-related progressions in story structure in young children's narratives. Journal of Speech, Language, and Hearing Research, 59(6), 13951408.

Kim, Y., \& Phillips, B. (2014). Cognitive correlates of listening comprehension. Reading Research Quarterly, 49(3), 269-281.

Kim, Y. J., \& Pae, S. (2004). Narrative abilities of Korean children with and without specific language impairment. The Korean Journal of Developmental Psychology, 17(1), 41-58.

Kim, Y. T., Hong, G. H., Kim, K. H., Jang, H. S., \& Lee, J. Y. (2009). Receptive \& expressive vocabulary test (REVT). Seoul: Seoul Community Rehabilitation Center.

Kim, Y. T., Sung, T. J., \& Lee, Y. K. (2003). Preschool receptive-expressive language scale (PRES). Seoul: Seoul Community Rehabilitation Center.

Kupersmidt, J. B., Coie, J. D., \& Dodge, K. A. (1990). The Role of poor relationship in the development of disorder. In S. R. Asher \& J. D. Coie (Eds.). Peer Rejection in Childhood (pp. 274-305). NY: Cambridge University Press.

Ladd, G. W. (1999). Peer relationships and social competence during early and middle childhood. Annual Review of Psychology, 50(1), 333-359.

Lafreniere, P. J. (1996). Co-operation as a conditional strategy among peers: influence of social ecology and kin relations. International Journal of Behavioral Development, 19(1), 39-52.

Lee, S. K. (2014). A study of children's emotional development -focused on emotional regulation. Global Social Welfare Review, 4(2), 79-97.

Leonard, L. B. (1998). Children with specific language impairment. Cambridge, MA: MIT press.
Liles, B. Z., Duffy, R. J., Merritt, D. D., \& Purcell, S. L. (1995). Measurement of narrative discourse ability in children with language disorders. Journal of Speech and Hearing Research, 38(2), 415-425.

Lindsay, G., Dockrell, J. E., \& Strand, S. (2007). Longitudinal patterns of behaviour problems in children with specific speech and language difficulties: child and contextual factors. British Journal of Educational Psychology, 77(4), 811-828.

Lynch, J. S., van den Broek, P., Kremer, K. E., Kendeou, P., White, M. J., \& Lorch, E. P. (2008). The development of narrative comprehension and its relation to other reading skills. Reading Psychology, 29(4), 327-365.

Magimairaj, B. M., \& Montgomery, J. W. (2013). Examining the relative contribution of memory updating, attention focus switching, and sustained attention to children's verbal working memory span. Child Development Research, 53(1), 1-12.

Marton, K., Abramoff, B., \& Rosenzweig, S. (2005). Social cognition and language in children with specific language impairment (SLI). Journal of Communication Disorders, 38(2), 143-162.

McClelland, M. M., \& Morrison, F. J. (2003). The emergence of learning-related social skills in preschool children. Early Childhood Research Quarter$l y, 18(2), 206-224$.

McFall, R. M. (1982). A review and reformulation of the construct of social skill. Behavioral Assessment, 4(2), 1-33.

Merrell, K. W. (1994). The preschool and kindergarten behavior scales. Austin, TX: PRO-ED.

Merritt, D. D., \& Liles, B. Z. (1987). Story grammar ability in children with and without language disorder: story generation, story retelling and story comprehension. Journal of Speech and Hearing Research, 30(4), 539-552.

Miyake, A., Friedman, N. P., Emerson, M. J., Witzki, A. H., Howerter, A., \& Wager, T. D. (2000). The unity and diversity of executive functions and their contributions to complex "Frontal Lobe" tasks: a latent variable analysis. Cognitive Psychology, 41(1), 49-100.

Moon, S. B., \& Byun, C. J. (2003). Korean Kaufman assessment battery for children $(K-A B C)$. Seoul: Hakjisa.

Morrow, L. M. (1985). Retelling stories: a strategy for improving young children's comprehension, concept of story structure and oral language complexity. The Elementary School Journal, 85(5), 647-661.

Mundy, P., \& Sigman, M. (2006). Joint attention, social competence and developmental psychopathology. In D. Cicchetti \& D. Cohen (Eds.), Developmental psychopathology, vol. 1: Theory and methods (2nd ed., pp. 293332). Hoboken, N. J.: Wiley. 
Norbury, C., \& Bishop, D. V. M. (2002). Inferential processing and story recall in children with communication problems: a comparison of specific language impairment, pragmatic language impairment and high-functioning autism. International Journal of Language and Communication Disorders, 37(3), 227-251.

Park, J. S. (2014). Emotion regulations of child and adolescent from developmental perspectives. Korean Journal of Health Psychology, 19(1), 1-21.

Parlade, M. V., Messinger, D. S., Delgado, C. E., Kaiser, M. Y., Hecke, A. V. V., \& Mundy, P. C. (2009). Anticipatory smiling: Linking early affective communication and social outcome. Infant Behavior and Development, 32(1), $33-43$.

Pekdoğan, S. (2016). Investigation of the effect of story-based social skills training program on the social skill development of 5-6 year-old children. Ted Eğitim Ve Bilim, 41(183), 305-318.

Redmond, S. M., \& Rice, M. L. (1998). The socioemotional behaviors of children with SLI: social adaptation or social deviance. Journal of Speech, Language, and Hearing Research, 41(3), 688-700.

Redmond, S. M., \& Rice, M. L. (2002). Stability of behavioural ratings of children with SLI. Journal of Speech, Language, and Hearing Research, 45(1), 190-201.

Remine, M. D., Care, E., \& Brown, M. P. (2008). Language ability and verbal and nonverbal executive functioning in deaf students communicating in spoken English. Journal of Deaf Studies and Deaf Education, 13(4), 531545.

Rhoades, B. L., Greenberg, M. T., \& Domitrovich, C. E. (2009). The contribution of inhibitory control to preschoolers' social-emotional competence. Journal of Applied Developmental Psychology, 30(3), 310-320.

Rice, M. L. (1993). 'Don't talk to him; he's weird.' A social consequences account of language and social interactions. In A. P. Kaiser \& D. B. Gray (Eds.), Communication and language intervention series: Vol 2. Enhancing children's communication: research foundations for intervention (pp. 139-158). Baltimore: Paul H. Brookes Publishing Co.

Roebers, C. M., \& Schneider, W. (2005). Individual differences in young children's suggestibility: relations to event memory, language abilities, working memory, and executive functioning. Cognitive Development, 20(3), 427447.

Rowsell, H. C., \& Coplan, R. J. (2013). Exploring links between shyness, romantic relationship quality, and well-being. Canadian Journal of Behavioural Science, 45(4), 287-295.

Ryu, K., \& Min, K. H. (2003). The development of preschooler's understand- ing of emotions: understanding of causes of emotions and regulations of emotions. Psychological Science, 12(2), 13-29.

Samuelson, L. K., \& Smith, L. B. (2000). Children's attention to rigid and deformable shape in naming and non-naming tasks. Child Development, 71(6), 1555-1570

Shure, M. B., \& Spivack, G. (1974). Social adjustment of young childrearing. SanFrancisco: Jossey - Bass.

Smith, L. B., Jones, S. S., \& Landau, B. (1996). Naming in young children: a dumb attentional mechanism?. Cognition, 60(2), 143-171.

Spaulding, T. J. (2010). Investigating mechanisms of suppression in preschool children with specific language impairment. Journal of Speech, Language, and Hearing Research, 53(15), 725-738.

Stanton-Chapman, T. L., Justice, L. M., Skibbe, L. E., \& Grant, S. L. (2007). Social and behavioural characteristics of preschoolers with specific language impairment. Topics in Early Childhood Special Education, 27(2), 98109 .

Stegge, H., \& Terwogt, M. M. (2007). Awareness and regulation of emotion in typical and atypical development. In J. J. Gross (Ed), Handbook of emotion regulation (pp. 249-268), New York: Guilford Press.

Stevens, L. J., \& Bliss, L. S. (1995). Conflict resolution abilities of children with specific language impairment and children with normal language. Journal of Speech and Hearing Research, 38(3), 599-611.

Storch, S. A., \& Whitehurst, G. J. (2002). Oral language and code-related precursors to reading: evidence from a longitudinal structural model. Developmental Psychology, 38(6), 934-947.

Timler, G. R. (2008). Social knowledge in children with language impairments: examination of strategies, predicted consequences, and goals in peer conflict situations. Clinical Linguistics \& Phonetics, 22(9), 741-763.

van den Broek, P., Kendeou, P., Kremer, K., Lynch, J. S., Butler, J., White, M. J., \& Lorch, E. P. (2005). Assessment of comprehension abilities in young children. In S. G. Paris \& S. A. Stahl (Eds.), Children's Reading Comprehension and Assessment (pp. 107-130). Mahwah, NJ: Erlbaum.

Vandell, D. L., \& Wilson, K. S. (1987). Infants' interactions with mother, sibling, and peer: contrasts and relations between interaction systems. Child Development, 58(1), 176-186.

Vandell, D. L., Wilson, K. S., \& Buchanan, N. R. (1980). Peer interaction in the first year of life: an examination of its structure, content, and sensitivity to toys. Child Development, 51(2), 481-488.

van Kleeck, A. (2008). Providing preschool foundations for later reading comprehension: the importance of and ideas for targeting inferencing in story- 
book-sharing interventions. Psychology in the Schools, 45(7), 627-643.

Vaughan, L., \& Giovanello, K. (2010). Executive function in daily life: age-related influences of executive processes on instrumental activities of daily living. Psychology and Aging, 25(2), 343-355.

Whaley, K. K. (1990). The emergence of social play in infancy: a proposed developmental sequence of infant-adult social play. Early Childhood Research Quarterly, 5(3), 347-358.

Whitely, C., \& Colozzo, P. (2013). Who's who? Memory updating and character reference in children's narratives. Journal of Speech, Language, and Hearing Research, 56(5), 1625-1636.

Yang, Y. H., \& Yim, D. S. (2018). The role of executive function for vocabulary acquisition and word learning in preschool-age children with and without vocabulary delay. Communication Sciences \& Disorders, 23(1), 1-17.

Yim, D., Park, W., Kim, S., Han, J., Song, E., \& Son, J. (2019). An eye-tracking study of picture book reading in preschool children with and without language delay. Communication Sciences \& Disorders, 24(2), 299-316.
Yim, D. S., \& Yang, Y. H. (2018). The relationship of nonlinguistic visual processing capacity, speed, and vocabulary ability in children with specific language impairment. Communication Sciences \& Disorders, 23(2), 451461.

Yim, D. S., Yang, Y. H., Jo, Y. J., Lee, J. Y., \& Seong, J. M. (2015). Grammatical meta-linguistic awareness and executive function skills in preschool-age children with and without specific language impairment. Journal of SpeechLanguage \& Hearing Disorders, 24(4), 347-361.

Yim, D. S., Yang. Y. H., \& Song, E. (2019). The relationships between the theory of mind, executive function, and language in preschool children with and without specific language impairment. Special Education Research, 18(3), 59-81.

Yoon, C. Y. (2008). A normative study of Korean social skill Inventory for preschoolers. Journal of Emotional \& Behavioral Disorders, 24(2), 157-173.

Yoon, C. Y. (2012). Korean-Social Skill Rating Scale for Preschoolers (K-SSRSP). Busan: Tespia. 
Appendix 1. Example of questions in Korean-Social Skill Rating Scale for Preschoolers (K-SSRSP; Yoon, 2012)

\begin{tabular}{ll}
\hline 영역 & \multicolumn{1}{c}{ 검사 문항 예시 } \\
\hline 문제해결 & 문제가 발생할 때 친사회적인 방법으로 해결한다. \\
& 게임에서 졌을 때 화를 내지 않고 받아들인다. \\
& 무엇이 공정하고 불공정한가를 알고 있다. \\
& 또래가 괴롭힐 때 적절하게 대처한다. \\
정서표현 & 어떤 활동이나 놀이에 즐겁게 참여한다. \\
& 자신이 원치 않거나 싫다는 의사표시를 분명히 말한다. \\
& 자신의 애정을 적절하게 표현한다. \\
& 화가 났을 때 말로 표현한다. \\
& 게임이나 활동을 맨 먼저 하려고 고집하지 않는다. \\
& 또래와 놀이나 게임을 할 때 규칙을 잘 지킨다. \\
& 또래와 장난감이나낙 교구를 사이좋게 공동으로 사용한다. \\
& 교사나 부모의 지시를 잘 따른다. \\
& 어떤 상황에서도 기가 죽지 않고 침착하다. \\
& 또래에게 자기 의사를 당당하게 말한다. \\
& 도움이 필요할 경우 다른 사람에게 당당하게 요청한다. \\
& 따래완감 갈등이 있을 때 목소리가 대담하며 자신이 있다. \\
\hline
\end{tabular}

Appendix 2. Peppa pig story comprehension task scoring sheet

페파피그 이야기 이해 과제 기록지

\begin{tabular}{|c|c|c|c|c|}
\hline & 이야기 이해 질문 & 예시답안 및 채점기준 & 0 & 2 \\
\hline 1 & $\begin{array}{l}\text { 페파는 여자친구들을 초대했어요. } \\
\text { 어디로 초대했나요? }\end{array}$ & 나무 위 노란 집, 빨간 지붕 집 & & \\
\hline 2 & 남자친구들은 어디에서 놀았나요? & $\begin{array}{l}\text { ‘할아버지가 만든 성’ 2점; } \\
\text { ‘파란 성’ 1점 }\end{array}$ & & \\
\hline 3 & $\begin{array}{l}\text { (의도추론) } \\
\text { 할아버지는 남자친구들에게 성을 만들어줬어요. } \\
\text { 왜 만들어줬을까요? }\end{array}$ & $\begin{array}{l}\text { 남자친구들의 속상한 감정에 대해 언급하면 2점; } \\
\text { '남자친구들은 집이 없으니까','여자친구들이 남자친구들을 } \\
\text { 집에 들어오지 못하게 해서' 1점 }\end{array}$ & & \\
\hline 4 & $\begin{array}{l}\text { (의도추론) } \\
\text { 남자친구들은 작고 동그란 도르래를 잡고 돌돌 돌렸지요. } \\
\text { 왜 그랬을까요? }\end{array}$ & $\begin{array}{l}\text { 여자친구들을 들어오지 못하게 하려는 의도를 산출하면 2점; } \\
\text { '성문을 닫으려고' 1점 }\end{array}$ & & \\
\hline 5 & 할아버지는 친구들에게 선물을 줬어요. 그 선물은 무엇이었나요? & 깡통전화기 & & \\
\hline 6 & $\begin{array}{l}\text { (의도추론) } \\
\text { 할아버지는 서로 연락하도록 깡통전화기를 주었어요. } \\
\text { 왜 그랬을까요? }\end{array}$ & $\begin{array}{l}\text { 여자친구들과 남자친구들을 화해시키려고, 사이 좋게 지내라 } \\
\text { 고, 싸우지 말라고 }\end{array}$ & & \\
\hline 7 & 깡통전화기를 받았을 때 페파는 좋아했나요? & 아니요. 실어했어요. & & \\
\hline 8 & $\begin{array}{l}\text { (감정추론, 의도추론) } \\
\text { 페파는 왜 깡통전화기로 남자친구들과 연락하는 것이 } \\
\text { 실었을까요? }\end{array}$ & $\begin{array}{l}\text { 사건과 감정을 언급하면 2점; } \\
\text { 사건 또는 감정만 언급하면 1점 } \\
\text { * 사건: 남자친구들이 여자친구들을 성에 들어오지 못하게 함 } \\
\text { * 감정: 여자친구들이 속상함, 삐짐 등 }\end{array}$ & & \\
\hline 9 & 친구들은 다 같이 빨간 지붕 아래로 갔어요. 왜 그랬나요? & 비를 피하려고(안 맞으려고) & & \\
\hline 10 & $\begin{array}{l}\text { (결과추론) } \\
\text { 비가 올 때, 할아버지가 만든 성에 그대로 남아있으면 어떻게 } \\
\text { 될까요? }\end{array}$ & $\begin{array}{l}\text { 비를 맞아 발생하는 결과(ex. 감기 걸려요)를 언급하면 2점; } \\
\text { '비를 맞아요.' 1점 }\end{array}$ & & \\
\hline 11 & $\begin{array}{l}\text { (의도추론) } \\
\text { 비가 그치자 동생 돼지는 왜 갑자기 바깥으로 뛰어 나왔을까요? }\end{array}$ & $\begin{array}{l}\text { 비가 그치니까 기분이 좋아서, 밖에서 놀고 싶어서, 밖에 진흙 } \\
\text { 이 있어서 놀고 싶어서 }\end{array}$ & & \\
\hline & 총점 & & & $/ 18$ \\
\hline
\end{tabular}




\section{국문초록}

\section{단순언어장애 아동 및 일반아동의 사회성 기술 및 집행기능과 이야기 이해 능력 간의 관계 문주희 · 임동선 \\ 이화여자대학교 언어병리학과}

배경 및 목적: 아동의 사회성 기술과 집행기능은 타인과 상호작용하고 다양한 상황에 대응하는데 필요하며, 이들은 언어능력과 연관 되어 있다. 따라서 본 연구에서는 아동의 사회성 기술, 집행기능, 이야기 이해 과제 수행을 비교하고, 사회성 기술과 집행기능이 이야기 이해 능력을 예측해주는지 살펴보고자 하였다. 방법: 만 4-7세의 단순언어장애 아동 14 명과 일반아동 19 명이 참여하였으며, 이들을 대 상으로 한국 유아 사회성 기술 검사(K-SSRSP; 윤치연, 2012)와 집행기능 및 이야기 이해 과제를 실시하였다. 결과: 사회성 기술 검사에 서 집단 간 주효과와 사회성 기술 영역에 따른 주효과가 유의하였다. 집행기능 중 억제 과제 및 전환 과제와 이야기 이해 과제에서 단순 언어장애 아동의 수행력이 일반아동보다 유의하게 낮았다. 이야기 이해 과제 수행력을 유의하게 예측하는 요인은 일반아동의 경우 갱 신 과제 수행력, 단순언어장애 아동의 경우 사회성 기술 중 문제해결과 정서표현 점수로 나타났다. 논의 및 결론: 본 연구를 통해 단순 언어장애 아동은 사회성 기술, 억제 및 전환 능력, 이야기 이해 능력에서 어려움이 있으며, 이들의 사회성 기술 중 문제해결과 정서표현 이 이야기 이해 능력을 예측함을 확인하였다. 이러한 결과는 단순언어장애 아동의 평가 및 중재 시 또는 부모나 주양육자 등 비전문가 에게 제언할 시 사회성에 관해 구체적으로 살펴볼 필요성을 제시한다.

핵심어: 사회성 기술, 집행기능, 이야기 이해, 단순언어장애

본 연구는 2020년 대한민국 교육부와 한국연구재단의 지원을 받아 수행된 연구임(NRF-2018S1A3A2075274).

\section{참고문헌}

김영태, 성태제, 이윤경(2003). 취학전 아동의 수용언어 및 표현언어 발달척도(Preschool receptive-expressive language scale, PRES). 서울: 서울장 애인종합복지관.

김영태, 홍경훈, 김경희, 장혜성, 이주연(2009). 수용· 표현 어휘력 검사(Receptive \& expressive vocabulary Test, REVT). 서울: 서울장애인종합복지관. 김유정, 배소영(2004). 학령전 단순언어장애아동과 정상언어발달아동의 이야기 능력. 한국심리학회지: 발달, 17(1), 41-58.

문수백, 변창진(2003). K-ABC 교육심리측정도구(Korean-Kaufman assessment battery for children, K-ABC). 서울: 학지사. 박지선(2014). 발달적 관점에서 본 아동·청소년의 정서조절. 한국심리학회지: 건강, 19(1), 1-21.

양윤희, 임동선(2018). 학령전기 어휘발달지연 및 또래 아동의 어휘습득을 위한 집행기능의 역할. Communication Sciences \& Disorders, 23(1), 1-17. 유경, 민경환(2003). 학령전기 아동의 정서 이해의 발달: 정서 원인과 정서 조절에 대한 이해. 심리과학, 12(2), 13-29.

윤치연(2008). 한국 유아 사회성 기술검사 표준화 연구. 정서 · 행동장애연구, 24(2), 157-173.

윤치연(2012). 한국유아사회성기술검사(Korean-Social skill rating scale for preschoolers, K-SSRSP). 부산: (주)테스피아(심리검사 전문기관).

이선경(2014). 아동 정서발달에 대한 고찰: 정서조절을 중심으로. 글로벌사회복지연구, 4(2), 79-97.

임동선, 박원정, 김신영, 한지윤, 송은, 손진경(2019). 그림책 읽기에서 일반아동 및 어휘발달지연 아동의 이야기 이해 능력 및 안구 운동 패턴 분석: 시 선추적기 연구. Communication Sciences \& Disorders, 24(2), 299-316.

임동선, 양윤희(2018). 단순언어장애 아동의 비언어 정보 처리용량, 처리속도 그리고 어휘능력 간의 관계. Communication Sciences \& Disorders, 23(2), 451-461.

임동선, 양윤희, 송은(2019). 학령전기 단순언어장애 아동 및 또래아동의 마음이론, 집행기능, 언어능력간의 관계. 특수교육, 18(3), 59-81. 임동선, 양윤희, 조연주, 이지연, 성지민(2015). 학령전기 단순언어장애 및 일반아동의 문법성 메타언어인식과 집행기능 수행능력 비교분석. 언어치료 연구, 24(4), 347-361. 
조윤주, 임동선(2020). 한국어-영어 이중언어 일반아동, 한국어 단일언어 일반아동 및 단순언어장애아동의 덩이짓기(chunking) 능력 비교. Communication Sciences \& Disorders, 25(2), 242-257.

채종옥(2001). 유아의 이야기 이해에 관한 연구들에 대한 고찰. 아동학회지, 22(1),227-240.

\section{ORCID}

문주희(제1저자, 대학원생 https://orcid.org/0000-0002-4526-2974); 임동선(교신저자, 교수 https://orcid.org/0000-0001-8254-9504) 